\title{
Use of Antioxidants for the Neuro-Therapeutic Management of COVID-19
}

\author{
Noemí Cárdenas-Rodríguez ${ }^{1, *, \dagger}$, Cindy Bandala ${ }^{2,3, \dagger}$, América Vanoye-Carlo ${ }^{1}$, Iván Ignacio-Mejía ${ }^{4}$, \\ Saúl Gómez-Manzo ${ }^{5}{ }^{(0)}$, Estefani Yaquelin Hernández-Cruz ${ }^{6}$, José Pedraza-Chaverri ${ }^{6}{ }^{(\mathbb{C}}$, \\ Liliana Carmona-Aparicio ${ }^{1}$ and Beatriz Hernández-Ochoa ${ }^{7}$
}

check for updates

Citation: Cárdenas-Rodríguez, N.; Bandala, C.; Vanoye-Carlo, A.;

Ignacio-Mejía, I.; Gómez-Manzo, S.; Hernández-Cruz, E.Y.;

Pedraza-Chaverri, J.;

Carmona-Aparicio, L.;

Hernández-Ochoa, B. Use of

Antioxidants for the

Neuro-Therapeutic Management of COVID-19. Antioxidants 2021, 10, 971. https://doi.org/10.3390/

antiox10060971

Academic Editor: Peter L. Oliver

Received: 8 May 2021

Accepted: 15 June 2021

Published: 17 June 2021

Publisher's Note: MDPI stays neutral with regard to jurisdictional claims in published maps and institutional affiliations.

Copyright: (C) 2021 by the authors. Licensee MDPI, Basel, Switzerland. This article is an open access article distributed under the terms and conditions of the Creative Commons Attribution (CC BY) license (https:// creativecommons.org/licenses/by/ $4.0 /)$.
1 Laboratorio de Neurociencias, Instituto Nacional de Pediatría, Secreatría de Salud, Ciudad de México 04530, Mexico; avanoyec@pediatria.gob.mx (A.V.-C.);

c_apariccio@ciencias.unam.mx (L.C.-A.)

2 Division de Neurociencias, Instituto Nacional de Rehabilitación, Secretaría de Salud, Ciudad de México 14389, Mexico; cbandala@inr.gob.mx

3 Escuela Superior de Medicina, Instituto Politécnico Nacional, Ciudad de México 11340, Mexico

4 Laboratorio de Medicina Traslacional, Escuela Militar de Graduados de Sanidad, SEDENA, Ciudad de México 11200, Mexico; labfisiologia.emgs@udefa.edu.mx

5 Laboratorio de Bioquímica Genética, Instituto Nacional de Pediatría, Secretaría de Salud, Ciudad de México 04530, Mexico; saulmanzo@ciencias.unam.mx

6 Departamento de Biología, Facultad de Química, UNAM, Ciudad de México 04150, Mexico; estefani.hernandez@quimica.unam.mx (E.Y.H.-C.); pedraza@unam.mx (J.P.-C.)

7 Laboratorio de Inmunoquímica, Hospital Infantil de México Federico Gómez, Secretaría de Salud, Ciudad de México 06720, Mexico; beatrizhb_16@comunidad.unam.mx

* Correspondence: noemicr2001@ciencias.unam.mx; Tel.: +52-55-1084-0900 (ext. 1425)

+ These authors contributed equally to this work.

\begin{abstract}
Coronavirus Disease 2019 (COVID-19), caused by Severe Acute Respiratory Syndrome Coronavirus 2 (SARS-CoV-2), is an emergent infectious disease that has caused millions of deaths throughout the world. COVID-19 infection's main symptoms are fever, cough, fatigue, and neurological manifestations such as headache, myalgias, anosmia, ageusia, impaired consciousness, seizures, and even neuromuscular junctions' disorders. In addition, it is known that this disease causes a series of systemic complications such as adverse respiratory distress syndrome, cardiac injury, acute kidney injury, and liver dysfunction. Due to the neurological symptoms associated with COVID-19, damage in the central nervous system has been suggested as well as the neuroinvasive potential of SARS-CoV-2. It is known that $\mathrm{CoV}$ infections are associated with an inflammation process related to the imbalance of the antioxidant system; cellular changes caused by oxidative stress contribute to brain tissue damage. Although anti-COVID-19 vaccines are under development, there is no specific treatment for COVID-19 and its clinical manifestations and complications; only supportive treatments with immunomodulators, anti-vascular endothelial growth factors, modulating drugs, statins, or nutritional supplements have been used. In the present work, we analyzed the potential of antioxidants as adjuvants for the treatment of COVID-19 and specifically their possible role in preventing or decreasing the neurological manifestations and neurological complications present in the disease.
\end{abstract}

Keywords: COVID-19; SARS-CoV-2; antioxidants; oxidative stress; neurological damage; neurotherapeutic management

\section{Introduction}

Coronavirus Disease 2019 (COVID-19) is a highly contagious and deadly infectious disease with a broad spectrum of clinical manifestations. COVID-19 is caused by Severe Acute Respiratory Syndrome Coronavirus 2 (SARS-CoV-2). It was first identified in Wuhan, Hubei, China at the beginning of December 2019 and was declared a global pandemic in March 2020, causing around of 140,000,000 cases and up to 3,000,000 deaths until now [1]. 
SARS-CoV-2 belongs to the Betacoronavirus genus from the Coronavirinae subfamily within the family of Coronaviridae and Nidovirales order. SARS-CoV-2 shares homology with other coronaviruses responsible for severe acute respiratory syndromes such as SARS$\mathrm{CoV}(\sim 79.5 \%$ homology), which was first recognized in Guangdon, China in November 2002 and MERS-CoV ( 50\% homology) identified in 2012 in Jeddah, Saudi Arabia [2]. Coronaviruses are enveloped positive single-stranded RNA viruses with large genomes ranging from $8.4-12 \mathrm{kDa}$ and round virions of $80-120 \mathrm{~nm}$ in diameter. The $5^{\prime}$ terminal portion contains the open reading frames from viral replication proteins, while the 3 'terminal encodes the structural proteins named spike (S), membrane (M), nucleocapsid (N), envelope (E), and haemagglutinin-esterase (HE) proteins. SARS-CoV-2 has a genome of $26-32 \mathrm{~kb}$ encoding six non-structural proteins involved in viral replication and four structural proteins [3]. The SARS-CoV-2 structure consists of a lipid bilayer where the glycoprotein type (spike) forms peplomers on the virion surface, giving it a crown-like morphology. The membrane protein spans three times the membrane surface and presents a short N-terminal ectodomain and a cytoplasmic tail, while the E protein travels twice the surface and is constituted by an $\mathrm{N}$ - and a C-terminal internal domain, a short ectodomain, a transmembrane domain, and a cytoplasmic tail. Some coronaviruses have a haemagglutinin esterase protein; the role of this has not been fully understood, however, in the SARS-CoV-2 genome, HE is not encoded [4].

The mutation rate of SARS-CoV-2 has been estimated to be between $0.84-1.12 \times 10^{-3}$ substitutions per site per year [2,5]. However, transmission of the SARS-CoV-2 virus and anti-virus treatments used for COVID-19 can favor genetic variability of the virus, contributing to its load, virulence, and the variability of neuropathological findings [6]. For example, the SARS-CoV-2 variant of spike protein D614G has been the most prevalent form in COVID-19 disease and has been linked to a higher viral load in the upper respiratory tract but not to an increase in disease severity [7]. A recent study identified 5775 genome variants, including almost 3000 missense mutations, 1965 synonymous mutations, 484 mutations in non-coding regions, 142 non-coding deletions, 100 in-frame deletions, 66 non-coding insertions, 36 stop-gained changes, 11 frameshift deletions, and two in-frame insertions $[2,8]$. It is essential to mention this because as the pandemic is still active, more variants are being identified; this has been reported internationally with the Indian variants, whose impact on the infection rate, as well as inducing severe symptoms of this infection, are still in progress.

SARS-CoV-2 is transmitted mainly by respiratory droplets moving from one person to another [9]. For a sensitive detection of COVID-19, the collection and testing of both upper and lower respiratory samples, including sputum and bronchoalveolar lavage fluid is recommended. Several research committees have suggested that RT-PCR for COVID-19 nucleic acid detection of nasopharyngeal and oropharyngeal swab sampling and further confirmation by next-generation sequencing is the best way to diagnose COVID-19 infection [10]. The main symptoms of COVID-19 are fever, shortness of breath, cough, fatigue, headache, myalgias, anorexia, and chest pain. Other manifestations could include diarrhea, sore throat, anosmia, ageusia, hemoptysis, sputum production, rhinorrhea, nausea, vomiting, skin rash, impaired consciousness, and seizures. The presence of comorbidities during COVID-19 infection such as hypertension, diabetes, chronic respiratory disease, cardiovascular disease, cancer, or advanced age can negatively impact the prognosis of the disease [11-13]. The systemic complications in COVID-19 include adverse respiratory distress syndrome, cardiac injury, acute kidney injury, and liver dysfunction [14]. In addition, damage to the central nervous system (CNS) has been linked to COVID-19 infection; initial neurological characterization of COVID-19 disease in a Wuhan cohort of COVID-19 patients showed a low incidence of neurological complications such as headache, nausea, and vomiting, however, more recent studies have reported that neurological manifestations of SARS-CoV-2 infection can reach more than 35\%, evidencing the neuro-invasive potential of SARS-CoV-2. Mild neurological dysfunctions such as anosmia and dysgeusia during COVID-19 are frequent, however, severe neurological disorders such as stroke and 
encephalopathies have also been reported, although less frequently. On the other hand, post-mortem brain studies have shown association between SARS-CoV-2 infection and pan-encephalitis and meningitis in addition to diffuse edema, gliosis with diffuse activation of microglia, and astrocytes infarctions in cortical and subcortical areas, subarachnoid and punctate hemorrhages, arteriosclerosis, hypoxic-ischemic injury, and inflammation [15]. Regardless of the lack of studies analyzing SARS-CoV-2 CNS invasion, there is information that suggests the presence of the virus in human brain tissue, such as the detection of SARSCoV-2 RNA in the cerebrospinal fluid of infected patients [16]. In addition, other human coronaviruses have shown to be able to infect neural cells [17]. Neurological manifestations as well as abnormalities in brain imaging have been reported during infections with SARS-CoV and MERS-CoV. Moreover, particles and genomic sequences of SARS-CoV have been detected in the post-mortem brain tissue of SARS patients as well as in cerebrospinal fluid. Data showed that SARS-CoV is presented in the thalamus, brainstem, hypothalamus, and cortex but not cerebellum in both humans and animals [18]. More recently and using human brain organoids as the experimental model, it has been shown that SARS-CoV-2 can damage the choroid plexus epithelium and impair the normal function of the blood brain barrier [19]. Politi and coworkers report the follow up of brain changes during COVID-19 development in three patients [20], and Bougakov et al. suggest the infection of brain tissue by SARS-CoV-2 by axonal transport through cranial nerves according to the route: nasal cavity olfactory nerve, olfactory bulb, pyriform cortex, and brainstem; the same route that has been demonstrated during HCoV OC43 infection of brain tissue [21,22]. However, the neurotropism of SARS-CoV-2 remains in debate.

Virus, such as SARS-CoV2, infection and replication in pneumocytes causes diffuse alveolar and interstitial inflammatory exudate and alveolar gas exchange disorders [23,24]. Gas exchange disorders are also linked to hypoxia in CNS by increasing anaerobic metabolism and edema. Moreover, SARS-CoV2 infection has been related to a low level of red blood cells (RBC) observed in COVID-19 patients. Several clinical reports have documented abnormal findings in different brain areas associated with blood vessel damage that led to stroke events $[25,26]$. Hypoxemia reported in COVID-19 patients could be in many cases silent (happy hypoxemia). However, low levels of oxygen lead to damage in several tissues and it has been suggested that this can increase infection by up regulation of furin (via HIF-1 $\alpha$ ), a host enzyme required for cleaving the $S$ protein of the SARS-CoV2 [27,28]. Hypoxemia has also been related to proinflammatory cytokines [29].

$\mathrm{CoV}$ infections are mainly associated with cytokine production, inflammation, and cell death, which are pathophysiological processes also related to redox imbalance or oxidative stress both in animal models and humans [30-33]. Evidence indicates that the participation of oxidative stress in the pathogenesis of COVID-19 is achieved by enhancing the production of reactive oxygen species (ROS) and causing an imbalance of the host antioxidant system. In addition, the pro-inflammatory state caused by some comorbidities has been suggested as a negative factor for COVID-19 prognosis. Respiratory hypoxia associated with COVID-19 infection could initiate a hypoxic state in the brain and thus trigger oxidative stress. It has been largely documented that hypoxia induces ROS production which are involved in inflammation and immune response. High levels of ROS are the main cause of redox imbalance, macromolecules peroxidation, and the opening of the permeability transition pores of the mitochondria, thus, cellular changes caused by oxidative stress could lead to cell death and contribute to brain tissue damage [34]. Moreover, the oxidative stress triggered by SARS-CoV-2 infections has been compared with the one involved in Parkinson's disease and has demonstrated the activation of nuclear factor kappa B (NF- $\mathrm{KB}$ ) [35]. It is important to consider that these pro-inflammatory processes are both central and systemic.

Currently, over 150 anti-COVID-19 vaccines are under investigation. In relation to treatment, dexamethasone and remdesivir appear to be promising medical therapies. However, to date a specific treatment for COVID-19 does not exist, and only supportive therapies are available. Until now anti-inflammatory drugs, immunomodulators, anti- 
vascular endothelial growth factors, modulating drugs, statins, or nutritional supplements have been studied as possible therapeutics agents [36]. The role of antioxidants as possible adjuvants in the neurological manifestations and complications of COVID-19 is reviewed in the present work.

\section{Pathophysiological Mechanisms of SARS-CoV-2 and Its Neurological Implications}

Cell entry of SARS-CoV-2 is mediated mainly by the interaction between the viral trimeric $S$ protein and the cellular angiotensin converting enzyme 2 (ACE2) receptor [37]. The SARS-CoV-2 spike protein determines host tropism by binding to cell receptors through its receptor-binding domain (RBD) and initiates fusion and infection processes. Trimeric $S$ protein has two functional subunits (S1 and S2). S1 binds to ACE2 receptors and induces conformational changes in S2, facilitating infection by membrane fusion. Two heptad (HR-1 and HR2) domains are present in the S2 subunit of the S protein, which play the central role in the fusion membrane during the infection process. The binding of the $S$ protein to ACE2 through the RBD-S1 subunit allows the combination of HR1 and HR2 to form a six-helix bundle core fusion structure $(6 \mathrm{HB})$ and enables the proximity of the virus to the cell membrane for fusion [38-40].

The ACE2-receptor is a type-I transmembrane receptor with a catalytic extracellular domain, one transmembrane domain, and a cytoplasmic carboxyl domain. The extracellular portion of the ACE-2 receptor is a zinc metallopeptidase catalytic site and the spike binding domain [41]. Similarly to SARS-CoV, SARS-CoV-2 binds to ACE-2 but with higher affinity (10 to 20-fold), being more pathogenic. Viral S-protein priming by cellular transmembrane protease serine 2 (TMPRSS2) exposes its binding S1 domain and fusion S2 domain. The S1 binding to the ACE-2 receptor induces its internalization by upregulation of the ADAM metallopeptidase domain 17 (ADAM 17) activity which cleaves ACE2 from the cell surface. S2 domain exposure starts the viral fusion process to gain entry into cells [39,42] and release the viral genome into the cytoplasm where host ribosomes translate a polypeptide chain $(\sim 800 \mathrm{KDa})$ that is auto-proteolytically cleaved by two proteases: papain like protease (PLpro) and 3-chyomotrypsin like protease (3CLpro), also called the main protease (Mpro), which are encoded in the viral genome and generate the no-structural proteins required for viral replication [43].

The main ACE-2 function is associated with the cleavage of the renin-angiotensinaldosterone system (RAAS) peptides and is a regulatory mechanism opposed to the effects of angiotensin II generated by ACE. RAAS is a neurohormonal regulatory system involved in blood pressure and electrolyte homeostasis. Angiotensinogen is produced by the liver and cleaved into angiotensin I (Ang I). ACE catalyzes Ang I conversion to angiotensin II (Ang II), which is the main RAAS metabolite and binds to angiotensin II type 1 receptors. Ang II actions include vasoconstriction, renal sodium reabsorption and potassium excretion, aldosterone synthesis, blood pressure elevation, and inflammatory and pro-fibrotic signaling. ACE-2 cleaves Ang II to Ang (1-7) and exerts vasodilatation, anti-inflammation, and anti-fibrotic effects by Mas receptor system activation. RAAS activation effects depend on the tissue ACE/ACE2 balance, which could be affected by several factors [44-46].

ACE and ACE2 expression have been reported in almost all tissues such as vascular endothelia, lungs, brain, intestine, colon, heart, testis, pancreas, eye, thyroid, adipose tissue, gallbladder, and kidneys $[47,48]$. Interaction between SARS-CoV-2 and the ACE-2 receptor could affect the ACE/ACE2 balance, causing high levels of Ang II and activating Ang II/ AT1R signaling. Tissues expressing elevated ACE2 are potential targets for SAR-CoV2 infection, such as intestine, kidney, testis, gallbladder, and heart [48]. Because of the virus transmission mechanism, the lung is the main target organ for SARS-CoV-2. After entrance of SARS-CoV-2 into pneumocytes vascular permeability and inflammation have been reported, which has been related to ACE-2 downregulation. In addition, studies have demonstrated that Ang II level has a positive correlation with viral load and lung injury. In vitro studies have demonstrated that AT1R activation by Ang II can induce apoptotic death of lung epithelial cells. It has been shown that Ang II induces endothe- 
lial damage by cyclooxygenase (COX-2) activation, which in turn generates vasoactive prostaglandins and reactive oxygen species (ROS) $[49,50]$. The excessive production of ROS can then over activate AngII/AT1R/nicotinamide adenine dinucleotide phosphate (NADPH) oxidase axis and subsequently induce apoptosis by mitochondrial injury [51]. Release of cytochrome C, activation of caspase 3, and p38 mitogen activated protein kinase (MAPK)/Jun N-terminal kinase (JNK) cascade activation have been related to elevated ROS levels. Moreover, the entry of SARS-CoV-2 can cause destruction of lung cells by activating a local immune response mediated by macrophages and monocytes; these cells release cytokines such as interleukin-6 (IL-6), interferon- $\gamma$ (IFN- $\gamma$ ), monocyte chemoattractant protein-1 (MCP-1) interferon- $\gamma$-inducible protein-10 (IP-10), or tumor necrosis factor (TNF) into the blood of patients, thus being indicators of T-cells activation. Other inflammatory pathways activated by Ang II involve the transcriptional nuclear factor NF-kB and the expression of proinflammatory cytokines such as IL-6, IL-1 $\beta$, and TNF $\alpha$ [52]. In COVID-19 patients, an excessive cytokine release has been documented, which induces an increase in leukocyte recruitment to different body organs leading to multi-organ failure and could result in acute heart injury or acute renal injury. This phenomenon is called cytokine storm syndrome, it also occurs in other viral diseases such as SARS, MERS, and influenza. The result of the ACE2 protection loss is a hyperinflammatory state which can be seen the late phase of COVID-19 [53].

Previous studies on SARS-CoV and MERS-CoV have shown that coronaviruses are able to infect CNS cells in the brainstem, which suggests than infection of this brain region during COVID-19 could compromise respiratory and cardiovascular function [54]. However, the SARS-CoV receptor is different to the MERS-CoV one, which has been reported use Dipeptidyl peptidase 4 (DPP4) to gain access into different tissues, among them the cerebral cortex $[55,56]$. In relation to the entry of SARS-CoV-2 in CNS, it has been shown that ACE2 expression is highest in the amygdala, pons, and medulla oblongata and then also related to the susceptibility of the subject to respiratory distress [57]. It has been proposed that the SARS-CoV-2 neurovirulence could be related to the degree of expression of the ACE2 receptor in the regions of the CNS [58]

Employing an animal model demonstrated that SARS-CoV accessed brain tissue through the olfactory bulb, data that can be related to anosmia generated during COVID19 [59]. Moreover, it has been suggested that ACE2 could mediate SARS-CoV-2 neurotropism since it is expressed in neurons, astrocytes, and oligodendrocytes, mainly in the substantia nigra, ventricles, middle temporal gyrus, posterior cingulate cortex, and olfactory bulb as well as endothelial cells. In humans, ACE2 has a relatively high expression in the middle temporal gyrus and posterior cingulate cortex but is low in the hippocampus. Its expression has been showed also in the tractus solitarius nucleus, paraventricular nucleus, and rostral ventrolateral medulla, which are regions implicated in cardiovascular regulation $[48,60]$. Importantly, it has been demonstrated that SARS-CoV-2 can disrupt the brain blood barrier and gain access to brain tissue [19].

Currently, the mechanisms by which SARS-CoV-2 can disturb neurological functions are not known. However, some hypotheses have been proposed. The first one states that the neurological manifestations rise due to direct neurotropic action of the virus causing encephalitis or meningitis; the virus enters the CNS. Virus entry could be from direct blood circulation infecting vascular endothelium, through nasal cells invading the olfactory epithelium along the nerve to the olfactory bulb, or by leukocyte migration across the BBB and neuronal pathways to the Virchow-Robin space surrounding arterioles and venules, and into the lymphatic systems and receptors $[47,61]$. The other mechanism that has been proposed is the parainfectious disease mechanism, which results in immune-mediated nerve disturbance such as Guillain-Barre syndrome or Miller Fisher syndrome [62]. In addition, it has been shown that the existence of some risk factors predisposes patients with COVID-19 to neurological complications. Among the most common are older age and the presence of comorbidities, particularly hypertension and smoking since stimulation of the nicotinic acetylcholine (nACh) receptor could increase ACE2 expression in neurons [63]. 
However, further research is needed in order to clear the mechanism by which SARS-CoV-2 affects brain tissue due to the low expression of ACE2 in human brain [48]

Regardless of the kind of interaction between SARS-CoV-2 and brain tissue, the effects on the CNS are present during COVID-19 disease. Among the most common are smell impairment with normal nasal mucosa and normal imagining of olfactory bulbs; cerebrovascular disease, mainly ischemic events in small and large vessels. Stiff neck, confusion changes in mental status, or seizures have also been reported. Related to peripheral nerves, injury to cranial nerves and muscles has been associated with facial weakness, difficulty breathing, and trouble standing or walking [64]. Cytokine increased production (IL-6, IL-8, IL-10, I, and TNF- $\alpha$ ) and microglial activation has been observed in post-mortem brain tissue, and T-cell infiltration has been described in post-mortem brain tissue through mild perivascular infiltration [65], oxidative stress triggered by hypoxia, hypercoagulation and thrombosis [66], gut microbiome dysbiosis [67], unfolded protein response, and accumulation of misfolded proteins such as amyloid-beta/tau/alpha-synuclein [68] and neurological autoimmune response [62], which are the main events that could explain the neurological symptoms during COVID-19.

COVID-19 infection produces mild neurologic manifestations such as headache and loss of smell. Globally, asthenia, myalgia, headache, anosmia, and ageusia are the most common symptoms, followed by encephalopathy, stroke, and seizures [3]. Near to $36 \%$ of COVID-19 patients exhibit neurological symptoms, including both central and peripheral signs. The hypercoagulation state observed during COVID-19 disease also affects CNS integrity and damage to the brain vasculature has been observed in $2 \%$ of patients [69-72].

Encephalopathy is considered the most common CNS complication of COVID-19 [73]; about $50 \%$ of the hospitalized COVID-19 cases develop it [74]. In addition, age and preexistent cognitive impairment, several comorbidities, malnutrition, concomitant infections, metabolic disorders, liver, vascular, and kidney dysfunctions, and sepsis are considered risk factors for neurological damage in COVID-19 patients [6]. Anatomopathological findings in the post-mortem brain tissue of COVID-19 patients are the presence of neuroinflammation with encephalitis, hemorrhagic lesions, infarctions, thrombosis, acute cerebral and cerebellar hypoxia-related lesions, reactive gliosis, astrocytosis, and microglia activation, showing a relationship between SARS-CoV-2 and central nervous system sequelae [75]. Table 1 shows the brain damage or neurological manifestations induced by COVID-19 infection reported in clinical cases.

Table 1. Neurological manifestations in patients infected with COVID-19.

\begin{tabular}{ccc}
\hline Type & Neurological Complications after COVID-19 Infection & Patients' Origin \\
Encephalitis & Italy \\
Meningoencephalitis & Iran \\
Cord myelopathy encephalitis & Brazil \\
Hypoxic encephalitis & United Kingdom \\
Autoinmune meningoencephalitis & India \\
Acute-disseminated encephalomyelitis & Egypt \\
Autoimmune encephalitis & Mexico \\
Diffuse post hypoxic leukoencephalopathy & Canada \\
Acute necrotizing encephalopathy & Spain \\
Guillain-Barré Syndrome & South Africa \\
Inflammatory & Netherlands \\
Guillain-Barré Syndrome associated with a cerebral & Belgium \\
vasculitis-like pattern & France \\
Cerebillitis & Peru \\
Mixed inflammatory cell & Japan \\
Posterior reversible encephalopathy syndrome & Germany \\
& Sweden \\
\hline
\end{tabular}


Table 1. Cont.

\begin{tabular}{|c|c|c|c|}
\hline Type & Neurological Complications after COVID-19 Infection & Patients' Origin & References \\
\hline Vascular & $\begin{array}{c}\text { Hemorrhage (intracerebral, subarachnoid, } \\
\text { and intracranial) } \\
\text { Multi-territory hemorrhagic infarctions } \\
\text { Microbleeds masquerades } \\
\text { Cerebral venous sinus thrombosis } \\
\text { Embolic stroke in the right insula and left cerebellum } \\
\text { Microinfarcts throughout the cortex } \\
\text { Posterior cerebral artery infarct } \\
\text { Middle cerebral artery territory infarcts } \\
\text { Cuffing of intracerebral blood vessels distant from } \\
\text { the infarcts } \\
\text { Left cerebral small subdural hematoma with mild } \\
\text { brain edema } \\
\text { Vasculitis } \\
\text { Perfusion abnormalities in brain } \\
\text { Large vessel stroke } \\
\text { Small subcortical infarcts } \\
\text { Brain microvascular occlusive disorder } \\
\text { Secondary acute ischemic stroke }\end{array}$ & $\begin{array}{l}\text { United States } \\
\text { South Africa } \\
\text { Switzerland } \\
\text { Germany } \\
\text { Mexico } \\
\text { India } \\
\text { Saudi Arabia } \\
\text { Brazil } \\
\text { Japan } \\
\text { Italy } \\
\text { Spain } \\
\text { China } \\
\text { Turkey }\end{array}$ & {$[95,97,106,109-126]$} \\
\hline Sensorial & $\begin{array}{c}\text { Headache } \\
\text { Vertigo } \\
\text { Anosmia } \\
\text { Ageusia } \\
\text { Altered taste } \\
\text { Migraine-like features } \\
\text { Vision impairment } \\
\text { Dizziness }\end{array}$ & $\begin{array}{c}\text { Spain } \\
\text { India } \\
\text { Egypt } \\
\text { China } \\
\text { Canada } \\
\text { Italy } \\
\text { Turkey } \\
\text { Germany } \\
\text { United States } \\
\text { Venezuela } \\
\text { Bolivia }\end{array}$ & {$[72,97,98,127-132]$} \\
\hline Behavioral & $\begin{array}{c}\text { Confusion } \\
\text { Seizure } \\
\text { Convulsions } \\
\text { Cognitive decay } \\
\text { coma } \\
\text { Neuropsychiatric disorder } \\
\text { Delirium } \\
\text { Maniac-like symptoms } \\
\text { Depression } \\
\text { Altered mental status } \\
\text { Psychosis } \\
\text { Dementia-like syndrome } \\
\text { Dysexecutive syndrome }\end{array}$ & $\begin{array}{c} \\
\\
\text { France } \\
\text { China } \\
\text { Iran } \\
\text { Egypt } \\
\text { Saudi Arabia } \\
\text { Belgium } \\
\text { Spain } \\
\text { India } \\
\text { United Kingdom }\end{array}$ & {$[69,72,96-98,125,133-138]$} \\
\hline Peripheral & $\begin{array}{c}\text { Peripheral neuropathy } \\
\text { Myasthenia gravis } \\
\text { Symmetric hypokinetic-rigid syndrome } \\
\text { Cranial neuropathy } \\
\text { Nerve pain } \\
\text { Bell's palsy } \\
\text { Balint-Holmes' syndrome } \\
\text { Ataxia } \\
\text { Anti-diuretic hormone secretion }\end{array}$ & $\begin{array}{l}\text { Belgium } \\
\text { Egypt } \\
\text { Spain } \\
\text { China } \\
\text { India } \\
\text { Italy }\end{array}$ & {$[72,97-99,135,139,140]$} \\
\hline Anatomical lesions & $\begin{array}{c}\text { Transtentorial herniation } \\
\text { Cytotoxic lesions of the corpus callosum } \\
\text { Diffuse corticospinal tract } \\
\text { Brain and spine demyelinating lesions } \\
\text { Pneumocephalus }\end{array}$ & $\begin{array}{l}\text { United States } \\
\text { Italy } \\
\text { Saudi Arabia } \\
\text { France }\end{array}$ & {$[69,125,126,141-144]$} \\
\hline
\end{tabular}




\section{Pharmacological Treatment for Patients with Neurological or Psychiatric Manifestations Associated with COVID-19}

General treatment of COVID-19 patients has been directed toward reducing symptomatic manifestations and maintaining vital functions, controlling comorbidities, and preventing secondary infections. World Health Organization (WHO) recommendations allow the use of some drugs with antiviral capacity for COVID-19 treatment: the antivirals lopinavir/ritonavir (Kaletra ${ }^{\circledR}$ ) affect proteolysis during SARS-CoV-2 replication cycle [145]; remdesivir is an adenosine analog able to incorporate into nascent viral RNA chains which results in premature termination [146]; and chloroquine and hydroxychloroquine, which have been traditionally used as antimalarial agents inhibit viral entry, uncoating, assembly, and budding processes [147]. In addition, other agents have been used or proposed to diminish the damage induced by COVID-19 such as: tocilizumab, an immunosuppressive agent IL-6 receptor antagonist [148]; antibiotics such as bafilomycin A1 [149] and Azithromycin, in combination with hydroxychloroquine [150]; anti-inflammatory agents as glucocorticoids [20]; JAK inhibitors such as baricitinib [151]; and micronutrients as vitamins [152].

Treatment and clinical management of patients with neurological manifestations in cases of severe or critical illness include mechanical ventilation and intensive care unit for life support. Vascular and inflammatory complications are the most common neurological effects during COVID-19 disease, so anticoagulants with low-molecular-weight are administered to the patients with coagulopathies and thromboprophylaxis to prevent stroke (nadroparin 2850-5700 IU sc per day, $5700 \mathrm{IU}$ per day with body weight $>100 \mathrm{~kg}$, or nadroparin $5700 \mathrm{IU}$ sc every $12 \mathrm{~h}$ ) [153], plus reperfusion therapy with alteplase $(0.9 \mathrm{mg} / \mathrm{kg})$ have been successfully used. In advanced COVID-19 disease, when anticoagulation with systemic heparin has failed, rescue therapy with tissue plasminogen activator (tPA) can be used to restore microvascular patency $[121,154,155]$. Due to the capacity of the antimalarial drug mefloquine to cross the $\mathrm{BBB}$, the use of chloroquine and hydroxychloroquine has been proposed as candidates to treat neuroinflammation induced by COVID-19 [156].

Psychiatric disorders reported that for the management of anxiety and agitation in COVID-19 patients, the following drugs have been recommended and used successfully: in patients over 18 years of age with swallowing ability lorazepam $0.5-1 \mathrm{mg}$ orally four times a day (maximum $4 \mathrm{mg}$ in $24 \mathrm{~h}$ ) $[157,158]$, in elderly or debilitated patients the dose should be reduced to $0.25-0.5 \mathrm{mg}$ (maximum $2 \mathrm{mg}$ in $24 \mathrm{~h}$ ); for anxiety or agitation with inability to swallow it is recommended to use midazolam $2.5-5 \mathrm{mg}$ every $2-4 \mathrm{~h}$ as needed, and if frequently needed an infusion of $10 \mathrm{mg}$ over $24 \mathrm{~h}$. For delirium manifestations in patients with swallowing capacity, it is recommended to use $0.5-1 \mathrm{mg}$ of haloperidol at night and every $2 \mathrm{~h}$ when needed (maximum $10 \mathrm{mg}$ daily, or $5 \mathrm{mg}$ daily in elderly patients) and this can be administered subcutaneously; a higher initial oral dose is recommended $(1.5-3 \mathrm{mg})$ if the patient is very distressed or is causing immediate danger to others, as well as the addition of benzodiazepines such as lorazepam or midazolam [158] if the patient remains agitated. Olanzapine (10 $\mathrm{mg}$ per day) has also been successfully used in the treatment of severe COVID-19 and schizophrenia (tension, panic, anxiety, aggression, and paranoia); midazolam, diazepam, and dexmedetomidine were administered to relieve anxiety and aid sleep [158,159]. In addition, agomelatine use $(36 \mathrm{mg} /$ day and $72 \mathrm{mg} /$ day orally in four doses) has been reported to improve the capacity for sleep [160]. Intravenous valproic acid (titrated to $1250 \mathrm{mg}$ per day) has been used in patients with COVID-19 for the management of agitation and hyperactive delirium symptoms and to facilitate tapering of multiple other delirium-sedative medications [161]. Some authors recommend candidate drugs to treat delirium in COVID-19 patients, such as melatonin, dexmedetomidine, clonidine, $\alpha-2$ agonists, and guanfacine [162,163]. The treatment protocols used in clinical cases of neurological or psychiatric manifestations induced by COVID-19 are summarized in Table 2. 
Table 2. Treatment protocols for neurological or psychiatric manifestations induced by COVID-19.

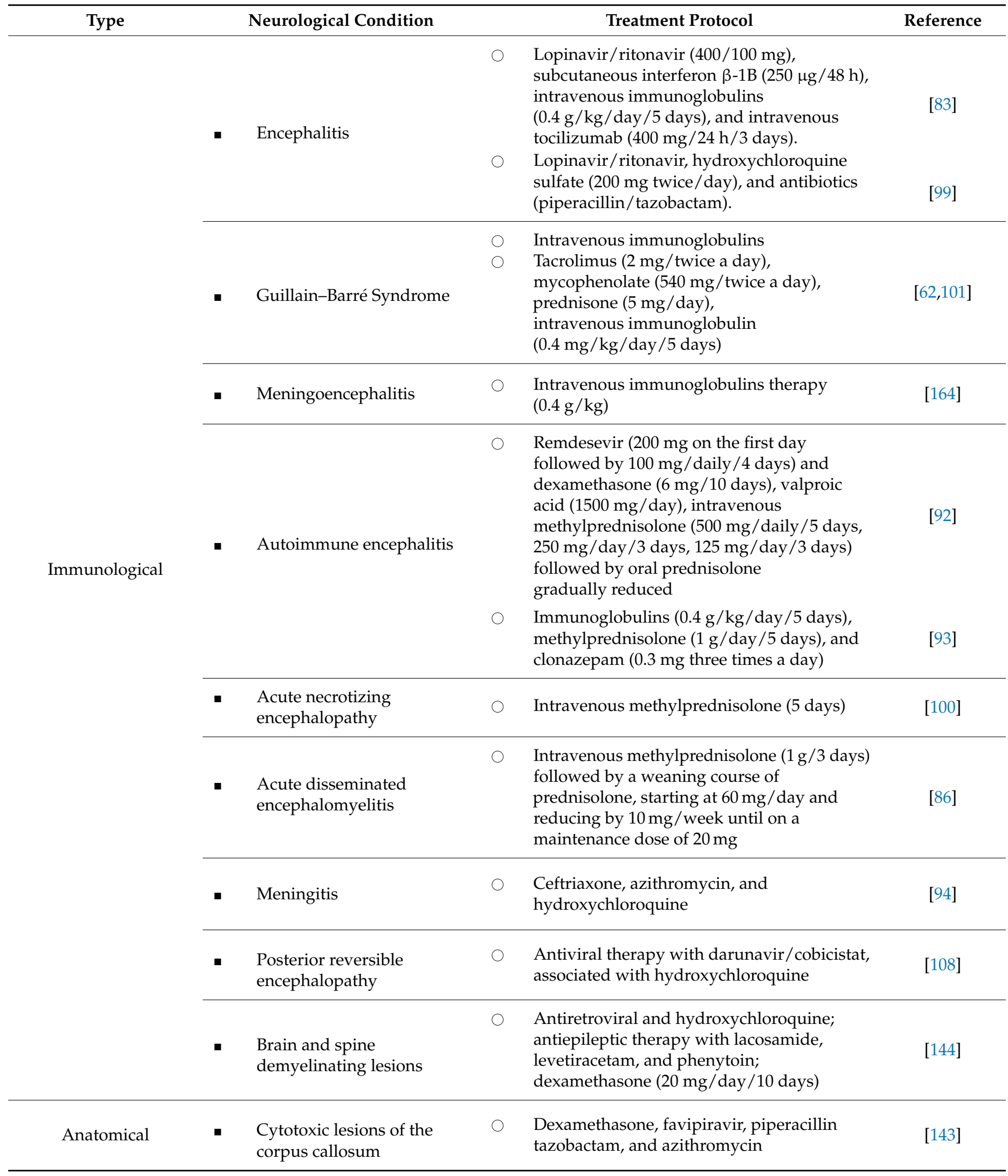


Table 2. Cont.

\begin{tabular}{|c|c|c|c|c|}
\hline Type & Neurological Condition & & Treatment Protocol & Reference \\
\hline \multirow{3}{*}{$\begin{array}{l}\text { Behavioral or } \\
\text { Psychiatric }\end{array}$} & - $\quad$ Maniac-like symptoms & $\bigcirc$ & $\begin{array}{l}\text { Arbidol Tablets, Moxifloxacin, Darunavir } \\
\text { and Cobicistat Tablets, and } \\
\text { methylprednisolone intramuscular injection } \\
\text { ( } 5-2.5 \mathrm{mg} \text { haloperidol twice/day) on the first } \\
2 \text { days of the maniac-like attack, combined } \\
\text { with olanzapine which was gradually } \\
\text { titrated to } 10 \mathrm{mg} / \text { day }\end{array}$ & [99] \\
\hline & Delirium & $\bigcirc$ & $\begin{array}{l}\text { 10-day course of oral hydroxychloroquine } \\
\text { therapy }(200 \mathrm{mg} / 8 \mathrm{~h} / 10 \text { days }) \text { as well as a } \\
\text { course of intravenous } \\
\text { piperacillin/tazobactam }(1 \mathrm{~g} / 8 \mathrm{~h} / 7 \text { days })\end{array}$ & [136] \\
\hline & $\begin{array}{l}\text { - Acute hypokinetic-rigid } \\
\text { syndrome }\end{array}$ & $\bigcirc$ & $\begin{array}{l}\text { Hydroxychloroquine }(200 \mathrm{mg} / 12 \mathrm{~h} / 10 \text { days }) \text {, } \\
\text { lopinavir/ritonavir } \\
(400 / 100 \mathrm{mg} / 12 \mathrm{~h} / 12 \text { days }) \text {, interferon } \beta \\
(0.25 \mathrm{mg} / 6 \text { days }), \text { ceftriaxone } \\
(2 \mathrm{~g} / 24 \mathrm{~h} / 10 \text { days), Tocilizumab } \\
(680 \mathrm{mg} / 1 \text { day), azithromycin } \\
(500 \mathrm{mg} / 24 \mathrm{~h} / 5 \text { days }), \text { methylprednisolone } \\
(250 \mathrm{mg} / 24 \mathrm{~h} / 3 \text { days), and levetiracetam } \\
(1000 \mathrm{mg} / 12 \mathrm{~h} / 4 \text { days })\end{array}$ & [139] \\
\hline \multirow{5}{*}{ Vascular } & $\begin{array}{l}\text { - Secondary acute } \\
\text { ischemic stroke }\end{array}$ & O & $\begin{array}{l}\text { Atorvastatin ( } 20 \mathrm{mg} \text {, p.o., q.d.), tirofiban } \\
(0.1 \mu \mathrm{g} / \mathrm{kg} . \mathrm{min} \text {, continuous intravenous } \\
\text { pumping for } 48 \mathrm{~h}) \text {, daily aspirin } \\
(100 \mathrm{mg} \text {, p.o. }) \text {, and clopidogrel }(75 \mathrm{mg} \text {, p.o. })\end{array}$ & [110] \\
\hline & $\begin{array}{l}\text { Brain microvascular } \\
\text { occlusive disorder }\end{array}$ & $\bigcirc$ & $\begin{array}{l}\text { Steroids, hydroxychloroquine, and } \\
\text { ceftaroline with a prophylactic dose of } \\
\text { enoxaparin ( } 6000 \mathrm{U} \text { once/day) }\end{array}$ & [116] \\
\hline & - Subarachnoid hemorrhage & $\bigcirc$ & Heparin infusion, $\mathrm{tPA}(2.0 \mathrm{mg} / \mathrm{h})$ & [120] \\
\hline & - Large-vessel stroke & $\bigcirc$ & Apixaban, aspirin, tPA and clopidogrel & [113] \\
\hline & $\begin{array}{l}\text { - Cerebral venous } \\
\text { sinus thrombosis }\end{array}$ & $\bigcirc$ & $\begin{array}{l}\text { Enoxaparin anticoagulation treatment and } \\
\text { prophylactic Levetiracetam infusion }\end{array}$ & [125] \\
\hline
\end{tabular}

\section{Role of Oxidative Stress and Antioxidant System in Patients with COVID-19}

Reactive oxygen species (ROS) are derived from molecular oxygen but are more reactive than oxygen itself. The term ROS includes free radicals and non-radicals [165]. For example, ozone $\left(\mathrm{O}_{3}\right)$, singlet oxygen $\left({ }^{1} \mathrm{O}_{2}\right)$, superoxide anion $\left(\mathrm{O}_{2}{ }^{\bullet-}\right)$, hydrogen peroxide $\left(\mathrm{H}_{2} \mathrm{O}_{2}\right)$, and hydroxyl radical $\left({ }^{\bullet} \mathrm{OH}\right)$ are considered ROS. ROS play an essential role in viral infections by inducing innate immune responses due to the opening of interendothelial junctions that allow the migration of inflammatory cells through the endothelial barrier [166,167]. The recruitment of inflammatory cells at the site of infection causes excessive ROS production, which is considered essential for the genesis and progression of inflammatory diseases [168,169]. Furthermore, the increase in ROS levels has been shown to stimulate the severity of viral infections due to their participation in inflammatory processes and the release and dissemination of virions [147]. Several respiratory viruses, including respiratory syncytial virus (RSV), human metapneumovirus (hMPV), MERS, SARS-CoV, and influenza increase ROS formation as a result of increased recruitment of inflammatory cells at the site of infection [170]. In these viral infections, the reduction of antioxidant enzymes expression and/or activity leads to a redox imbalance and consequent oxidative cell damage [170]. Similarly, during viral infection caused by SARS-CoV-2, in- 
creased oxidative stress has been proposed due to more significant migration of neutrophils to the infected area [171]. There is evidence that patients with severe COVID-19 present an increase in neutrophils and a decrease in lymphocytes levels, which could be an important factor in the severity of the disease [172-175]. The reduction of lymphocytes, particularly $\mathrm{T}$ cells, has also been related to oxidative stress. In a pro-oxidant environment, the essential regulatory proteins in $\mathrm{T}$ cells (such as cofilin or L-plastin) are oxidized, which could lead to the hypo-responsivity of these cells and even their death [156]. The ROS-mediated activation of transforming growth factor beta 1 (TGF- $\beta 1$ ) promoter during SARS-CoV infection has been documented. TGF- $\beta$ is a potent immunosuppressive cytokine acting on $T$ cells and could contribute to the decrease of lymphocytes in COVID-19 [176,177].

Another central mechanism that could contribute to ROS formation (including $\mathrm{O}_{2}{ }^{\bullet-}$ and $\mathrm{H}_{2} \mathrm{O}_{2}$ ) in COVID-19 patients is the activation of the enzyme nicotinamide adenine dinucleotide phosphate (NADPH) oxidase (NOX). NOX catalyzes the transfer of electrons from NADPH to molecular oxygen, producing $\mathrm{O}_{2}{ }^{\bullet-}$, and subsequently $\mathrm{O}_{2}{ }^{\bullet-}$ is transformed to $\mathrm{H}_{2} \mathrm{O}_{2}$ by the action of superoxide dismutase (SOD) [178]. There are seven different isoforms of NOX (NOX1-5 and DUOX1-2) with regulation and specific subcellular locations [179]. Isoform 2 (NOX-2) has been found to be overexpressed in hospitalized patients with COVID-19 and has been associated with increased oxidative stress [180].

NOX activation is regulated by the binding of angiotensin II (Ang II) to angiotensin type 1 (AT1R) [181]. The binding of SARS-CoV-2 to ACE2 causes the virus to enter cells and, in turn, reduces the bioavailability of ACE2 [182]. The reduction in the bioavailability of ACE2 makes Ang II interact with AT1R, with the subsequent activation of NOX and induction of oxidative stress and inflammatory responses [183]. ROS generated by this route could be related to an increase in viral load [184] due to the oxidation of cysteine residues in the peptidase domain of ACE2 receptors and in the carboxy-terminal receptorbinding domain (RBD) of SARS-CoV-2 peak proteins, maintaining them in oxidized forms (disulfide); the oxidation of these thiols causes an increase in the affinity of SARS-CoV-2 proteins for its ACE2 receptor, causing more viruses to enter cells [185,186]. Liu et al. [172] found elevated levels of angiotensin II in patients infected with SARS-CoV-2 that were directly proportional to the viral load and lung damage observed. Additionally, NOX activation reduces the bioavailability of nitric oxide (NO), leading to vasoconstriction, inflammation, redox imbalance, and endothelial dysfunction [172,187] in such a way that the classic RAAS, particularly the ACE2-Ang-(1-7) axis, becomes a powerful pro-oxidant system in COVID-19. Interestingly, NOX can also be activated by the release of TNF- $\alpha$ during the pro-inflammatory cytokine storm, contributing to local oxidative stress and endothelial dysfunction $[188,189]$. TNF- $\alpha$-induced ROS production could also contribute to the spread of COVID-19 symptoms to distant tissues such as the brain [190].

Oxidative stress in COVID-19 has also been linked to the release of iron into the bloodstream. SARS-CoV-2 attacks the heme groups of hemoglobin in red blood cells, producing the release of free Fe (III) ions into the bloodstream, which, through the Fenton and Haber-Weiss reactions, increases the ROS levels [191]. In addition, excess ROS causes the formation of methemoglobin, hemoglobin whose heme group has iron in the ferric state, Fe (III) (that is, oxidized). This type of hemoglobin cannot bind dioxygen, resulting in less efficient oxygen transport [171]. The effect of oxidative stress on red blood cells contributes to the hypoxic respiratory failure seen in the most severe cases of COVID-19 [151].

Mitochondria are the primary sources of ROS production in cells; therefore, mitochondrial dysfunction also plays an essential role in the oxidative stress observed in SARS-CoV-2 viral infection. Recent studies have hypothesized that the cytosolic ROS produced by NOX could trigger the opening of the adenosine triphosphate (ATP)-sensitive mitochondrial potassium channel (mitoK ATP) and the activation of the permeability transition pore (mPTP), causing the depolarization of the mitochondrial membrane and a burst of mitochondrial ROS production and the subsequent mitochondrial dysfunction [181]. Mitochondrial dysfunction has been linked to inflammation; this relationship occurs in both directions. Inflammatory mediators and immune sentinels trigger intracellular cascades 
that alter mitochondrial metabolism [192]. For example, TNF- $\alpha$ and interleukin (IL)-6 impair mitochondrial oxidative phosphorylation and coupled ATP production and trigger the production of mitochondrial ROS in the cell, leading to mitochondrial dysfunction, which has been found expressed in patients with COVID-19 [193,194]. Several studies have shown the impact of dysfunctional mitochondria on the immune response; a recent study revealed that human alveolar epithelial cells with dysfunctional mitochondria showed increased production of pro-inflammatory cytokines (CXCL-8, IL-6, CCL20, CCL3, CCL4, and IL-12), all of them increased in COVID-19 [195,196]. In the brain, hypoxia causes bioenergetic dysfunction of brain cells, also known as mitochondrial dysfunction. When a virus proliferates in lung tissue cells, it causes diffuse alveolar and interstitial inflammatory exudation, edema, and the formation of transparent membranes. This, in turn, leads to alveolar gas exchange disorders that cause hypoxia in the CNS, leading to mitochondrial dysfunction of brain cells [197].

As mentioned above, antioxidant systems are also affected by viral infections. Komaravelli and Casola [170] have associated respiratory viral infections with the inhibition of nuclear erythroid factor 2-related factor 2 (Nrf2) and activation of NF- $\mathrm{kB}$, phenomena that incline the balance to inflammation and oxidative damage during these infections [170]. In a study conducted on lung biopsies from patients with COVID-19, the Nrf2 pathway was found to be suppressed, while pharmacological inductors of Nrf2 have been observed to inhibit SARS-CoV-2 replication and the inflammatory response [198]. On the other hand, it is known that Nrf2 deficiency increases ACE2 availability, while activation produces the opposite, suggesting that Nrf2 activation in COVID-19 patients could reduce ACE2 availability for entry of SARS-CoV-2 in the cell [199]. However, it must be considered that Ang II would be overexpressed and, therefore, could contribute to the increase in oxidative stress, as previously explained. Nrf2 is a transcription factor whose target genes include those of proteins involved in cellular redox homeostasis, detoxification, macromolecular damage repair, and metabolic balance [200]; therefore, a decrease in Nrf2 could be related to the decrease in the enzymes that protect against oxidative stress including thioredoxin, thioredoxin reductase, peroxiredoxin, and those involved in glutathione (GSH) synthesis, among others.

It has been proposed that endogenous GSH deficiency could be one of the causes of severe symptoms in COVID-19 patients. The decrease in GSH and the increase in ROS were found to have a strong correlation with the worsening of symptoms and the slowest recovery times [201]. Furthermore, GSH deficiency causes an alteration in the genes that synthesize vitamin $\mathrm{D}$, resulting in a vitamin $\mathrm{D}$ deficiency and an increase in oxidative stress [201]. Likewise, it is known that GSH concentrations are decreased in the elderly [202], which could explain their susceptibility to the severity of COVID-19. In addition, in a study with elderly patients infected with the SARS-CoV-2 virus, a link was observed between the decreased expression of the antioxidant enzyme superoxide dismutase 3 (SOD3) and the severity of the disease [203]. It has also been proposed that GSH deficiency in a COVID-19 patient may be related to the increased NOX activity due to NOX using the coenzyme NADPH to carry out its reaction, reducing the concentration of free NADPH that is needed to regenerate GSH [204]. In Figure 1, we propose the mechanisms of neuronal damage and its relation to oxidative stress in COVID-19. 

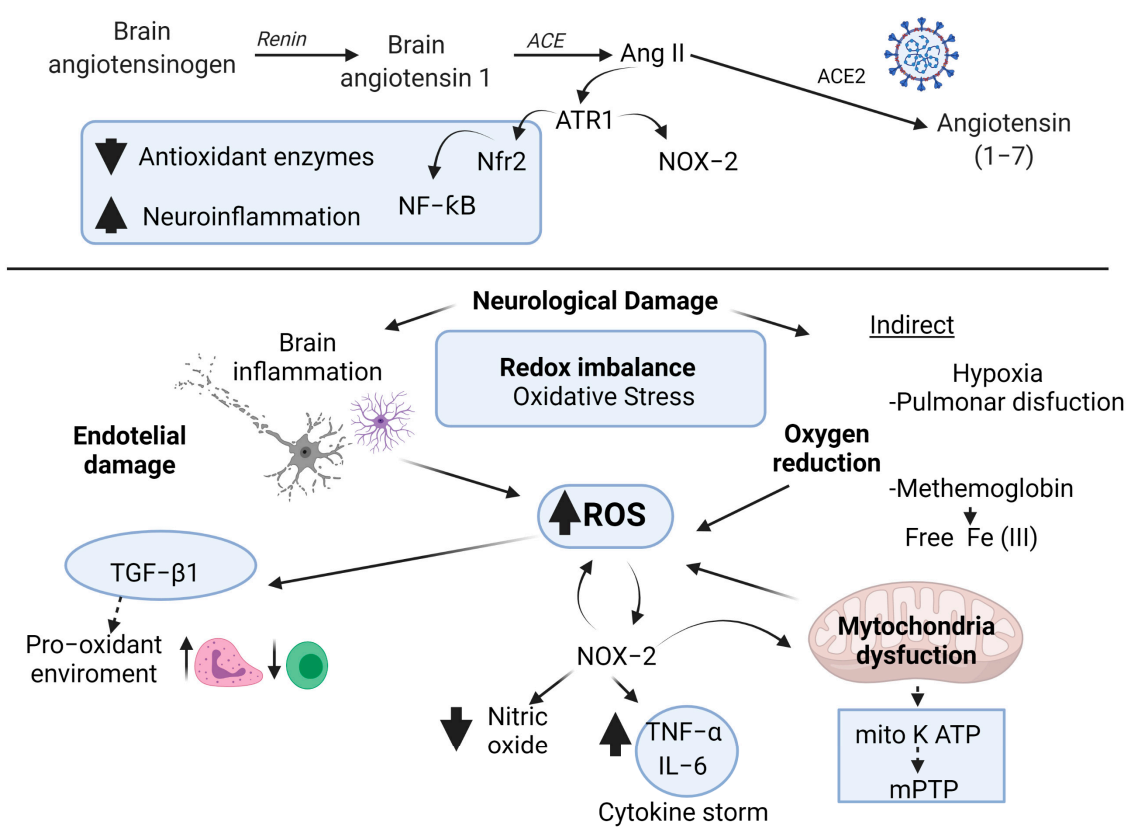

Figure 1. Possible mechanisms of neuronal damage related to redox imbalance in COVID-19. The recruitment of inflammatory cells increases ROS production. ROS levels have been shown to stimulate inflammatory processes and the release and dissemination of virions. An increase in neutrophils and a decrease in lymphocytes ( $\mathrm{T}$ cells) has also been related to pro-oxidant environment mediated activation of TGF- $\beta 1$. Another major mechanism that could be contributing to the ROS formation is the activation of the NOX-2. NOX-2 activation is regulated by the binding of angiotensin II (Ang II) to angiotensin type 1 (AT1R). The binding of SARS-CoV-2 to ACE2 causes the virus to enter cells and, in turn, reduces the bioavailability of ACE2. The reduction in the bioavailability of ACE2 makes Ang II interact with AT1R, with the subsequent activation of NOX and the induction of oxidative stress and inflammatory responses. NOX activation reduces the bioavailability of nitric oxide. NOX can also be activated by the release of TNF- $\alpha$ during the pro-inflammatory cytokine storm. SARS-CoV-2 attacks the heme groups of hemoglobin in red blood cells, producing the release of free Fe (III) ions into the bloodstream which, through the Fenton and Haber-Weiss reactions, increases the ROS levels. In addition, excess ROS causes the formation of methemoglobin, resulting in less efficient oxygen transport. In the brain, hypoxia causes bioenergetic dysfunction of brain cells, also known as mitochondrial dysfunction. Cytosolic ROS produced by NOX could trigger the opening of the adenosine triphosphate (ATP)-sensitive mitochondrial potassium channel (mitoK ATP) and the activation of the permeability transition pore $(\mathrm{mPTP})$ causing the depolarization of the mitochondrial membrane and a burst of mitochondrial ROS production and the subsequent mitochondrial dysfunction. TNF- $\alpha$ and interleukin (IL)-6 impair mitochondrial oxidative phosphorylation and coupled ATP production and trigger the production of mitochondrial ROS in the cell, leading to mitochondrial dysfunction. Respiratory viral infections have been associated with inhibition of nuclear erythroid factor 2-related factor 2 (Nrf2) and activation of NF- $\mathrm{kB}$. The decrease in Nrf has been related to a detriment in the production of antioxidant enzymes.

\section{Mechanisms of Antioxidants Compounds against SARS-CoV-2 in COVID-19}

The antioxidant activity of different compounds used in Chinese herbal medicine has been well documented and recently, some of them demonstrated their antiviral activity against SARS-CoV-2 [4,204]. Flavonoids are secondary plant phenolics and their bioactivity originates from their antioxidant and chelating capacity. Its chemical structure possesses a flavan nucleus and the number, position, and types of substitutions modify radical scavenging and chelating activity.

The antiviral effect of flavonoids and other antioxidant molecules against SARS-CoV-2 has been explored by means of molecular docking studies. The binding interactions of 
antioxidant compounds with S protein RBD and other SARS-CoV-2 proteins involved in COVID-19 infection have been studied. According to recent studies compounds like quercetin, withanolides, anaferine, ashwagandhanolide, nefamostat, hinokiflavone and robustaflavone showed high affinity for the S2 domain of the spike protein of SARS-CoV-2 $[205,206]$. These compounds interact with SARS-CoV-2 through its aromatic amino acid residues through non-covalent bonds (H-bonds) with the SARS-CoV-2 S2 protein. Moreover, hinokiflavone and robustaflavone interacted strongly with the residues of heptad repeat 1 and 2 regions of S2 proteins of SARS-CoV-2, inhibiting the fusion between the virus and target cell membranes [205]. Kamferol, curcumin, pterostilbene, and hydroxychloroquine have also been reported to interact with the C-terminal of the S1 domain and fisetin, quercetin, isorhamnetin, genistein, luteolin, resveratrol, and apigenin interact with the S2 domain of the SARS-CoV-2 spike protein [207].

$\mathrm{Su}$ and coworkers showed that baicalin and baicalein inhibited SARS-CoV-2 [208]. These compounds act as non-covalent, non-peptidomimetic inhibitors of SARS-CoV-2 3CLpro (main protease, Mpro). Baicalein works as a shield in front of two catalytic dyads and with high efficiency in the substrate-binding site at the surface of the protease [208]. Baicalin is also an ACE2 inhibitor [209]. Curcumin, quercetin, chrysin, kaempferol, luteolin melatonin, capsaicin, sesamin, cyanidins, demethoxycurcumin, epigallocatequin, hesperidin, myricitrin, puerarin, scutellarin, ursolic acid, glabiridin, apiin, rhoifolin, glycyrrhizin, vitexin, rutin, theaflavin-3-O-gallate, oolonghomobisflavan-A, bonducellpin $\mathrm{D}$, caesalmin B, 5,7-dimethoxyflavanone- $4^{\prime}-O-\beta$ - $d$-glucopyranoside, lupinifolin, pinocembrin 7-O-rutinoside methide quinone celastrol, andrographolide theasinensin-D, ebselen, galangin, ellagic acid, and coumarin analogues also inhibit SARS-Cov-2 replication. Those compounds interact with SARS-CoV-2 3CLpro in the binding pocket by hydrogen bonds, hydrophilic, and hydrophobic interactions [210-222].

Theaflavins, neohesperidin, naringenin, echinacoside, and salvianolic acid inhibited RNA-dependent RNA polymerase activity, blocking the active site of the groove (an active site for the polymerization of RNA but distal from the active site) through hydrophobic and hydrogen interactions [223,224]. Epigallocatechin gallate, theaflavin, and rutin digallate also show interactions with SARS-CoV-2 3CLpro, SARS-CoV-2 spike protein, and ACE2 receptor through a combination of hydrogen bonding, van der Waals and other hydrophobic interactions $[225,226]$. Utomo and coworkers showed that hesperidin, curcumin, brazilin, and galangin show anti-SARS-CoV-2 activities because of their high affinity for the $S$ protein RBD, PD-ACE2, and SARS-CoV-2 protease [227]. Additionally, asparosides, shatavarins, and racemoside-A also interact with $S$ protein RBD by hydrogen bonds [228].

Compounds such as flavonoids, iridoids, terpenes, diterpenes, and lignans were also reported as promising anti-SARS-CoV-2 treatments through interaction with TMPRSS2 through van der Waals and hydrogen bonds [229,230]. Ursonic acid, asparosides, racemoside-A, and rutin also show interaction with non-structural protein (Nsp)15 (an endoribonuclease essential for the virus life cycle) of SARS-CoV-2 via hydrogen bonds $[228,231]$. It has been shown that nigellidine interacts with the N-protein, and Nsp2, which has been suggested as disrupting the host cell environment by interacting with prohibitin host proteins (PHB and PHB2), is known to play roles in cell cycle progression, cell migration, cellular differentiation, apoptosis, and mitochondrial biogenesis. Nigellidine also binds to SARS-CoV-2 3CLpro and SARS-CoV-2 spike protein through diverse interactions and blocks the inflammatory markers IL1 and IL6 [232]. Additionally, it was shown that caffeic acid, ferulic acid anthrarufin, aloe-emodin, alizarine, dantron, and emodin interact with three active sites of RNA binding domains of nucleocapsid phosphoprotein of COVID-19 through hydrogen bonds and hydrophobic groups [233,234]. Finally, synthetic antioxidant compound derivatives of the pyrimidine and piperizine ring framework, polyhydroxy-1,3,4-oxadiazole, triazole, hesperidin, resveratrol derivatives and derivatives of natural products such as terpenoids and polyphenolic compounds have also shown interactions with SARS-CoV-2 3CLpro and RNA-dependent RNA poly- 
merase activity, principally by hydrogen bonds, hydrophobic groups and van der Waals forces [222,235-238].

Other antiviral mechanisms proposed by some authors against SARS-CoV-2 observed in antioxidant compounds are: (a) inhibition of the viral replication (i.e., curcumin and resveratrol) $[239,240]$, (b) blockage of the inflammatory response (i.e., resveratrol, curcumin, naringenin, and $\mathrm{N}$-acetil cysteine) [207,239-241], (c) inhibition of SARS-CoV-2 fusion/entry by interaction with SARS-CoV-2:ACE-2 interface (luteolin and dithymoquinone) [242,243], (d) as radical scavengers (i.e., methide quinone celastrol as superoxide radical scavenger or hydrogen as hydroxyl radical scavenger) [214,244], (e) inhibition of ACE activity (Nacetyl cysteine) [245], (f) modulation of endoplasmic reticulum stress (andrographolide and melatonin) [246], (g) activation of Nrf2 pathway (antioxidant mixture PB125 ${ }^{\circledR}$ ) [247], (h) antithromboembolics (hesperidin and diosmin mixture) [248], and (i) inducing aggregation of SARS-CoV-2 spike proteins and disruption of the viral genome (hydroxytyrosol) [249]. Figure 2 shows the mechanisms of antioxidants compounds that could prevent neuronal damage in patients with COVID-19

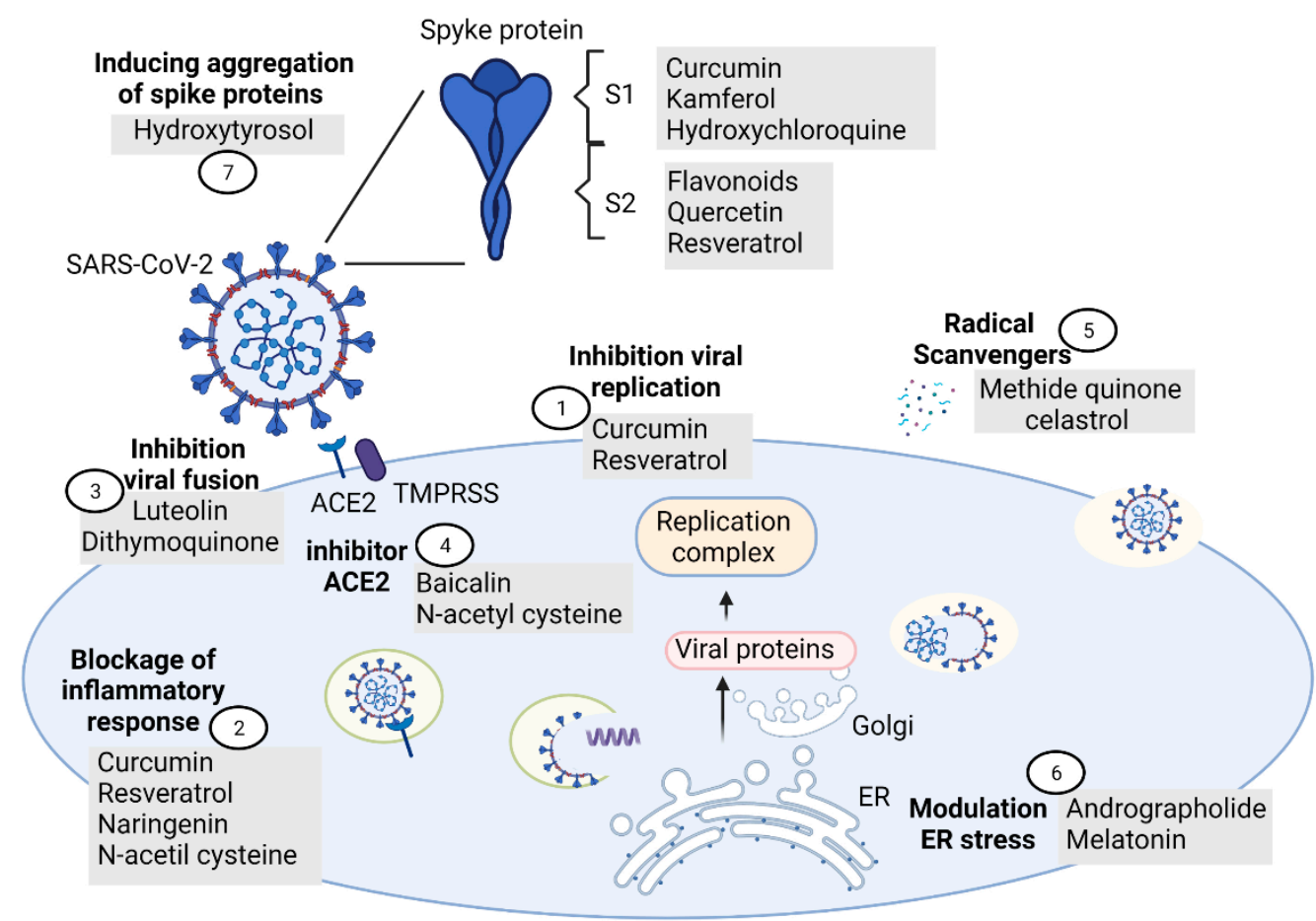

Figure 2. Mechanisms of antioxidant compounds that may possibly prevent and diminish neurological damage in patients with COVID-19. (1) Inhibition of the viral replication, (2) blockage of the inflammatory response, (3) inhibition of SARSCoV-2 fusion/entry by interaction with SARS-CoV-2:ACE-2 interface, (4) inhibition of ACE2, (5) radical scavengers, (6) modulation of endoplasmic reticulum stress, and (7) inducing aggregation of SARS-CoV-2 spike proteins and disruption of the viral genoma.

\section{Antioxidants as Neuroprotectors in Patients Infected with COVID-19}

Given that nutrition and diet are closely linked to oxidative processes, they could also play an important role in the development and the severity of this disease and could impact in the progression of COVID-19 in patients. Plus, quarantine has been associated with depression and stress and a decrease in physical activity and nutrition quality in the general population [250]. Therefore, changes in lifestyle and diet must be implemented not only in the patients infected with COVID-19 but also in healthy people in order to decrease SARS-CoV-2 infection spread and lousy prognosis. As has been mentioned, no specific antiviral drug is available to treat COVID-19, but therapeutic interventions have helped to control COVID-19 in the world [251,252]. In this sense, it has been proposed that 
antioxidant compounds can improve the prognosis of COVID-19 patients through different mechanisms, mainly by the reduction of inflammation [252,253].

Modulation of the immune system by nutrition has been largely studied. Vitamins A, C, D, B6, and B12, folate, zinc, iron, copper, and selenium play a role in the immune response [152]. During COVID-19 disease, it has been shown that these micronutrients have a therapeutic effect. Vitamin $C$ reduces inflammatory response, optimizes the immune system by modifying IL- 6 and TNF- $\alpha$ levels, and maintains vascular consistency through its potent antioxidant properties [254]. Vitamin D has shown therapeutic effects in the viral infection by mechanisms such as the increase of reduced glutathione [255]. Vitamin D has shown a therapeutic role in reducing renin-angiotensin-aldosterone system activation as well as normalizing mitochondrial dynamics $[256,257]$. Recently, Gao and coworkers, in a retrospective cohort study, showed that in patients with COVID-19 infection with a high-dose of vitamin $C$ ( $n=46$ patients, dose of $6 \mathrm{~g}$ intravenous infusion of vitamin $C$ per $12 \mathrm{~h}$ on the first day, and $6 \mathrm{~g}$ once for the following 4 days) in comparison with standard therapy group $(n=30)$ the risk of the mortality was lower $(\mathrm{HR}=9.91,95 \% \mathrm{CI}=1.82-54$; $\mathrm{HR}=7.98,95 \% \mathrm{CI}=1.24-51.22)$ in 28 days of therapy. The oxygen support status was also improved in patients with high-dose of vitamin C $(63.9 \%)$ in comparison with patients in the standard therapy group (36.1\%) over a median retrospective time of 18 days. In addition, the patients with a high dose of vitamin $C$ had reduced serum high sensitivityC-reactive protein, procalcitonin and IL-8 levels in comparison with the standard group. Finally the patients with a high dose of vitamin C did not show adverse effects [258]. In a retrospective case series study, vitamin $C$ significantly decreased serum $C$-reactive protein from 0 to 3 after 7 days of administration in six patients infected with severe and six patients with critical COVID-19. The dosage of vitamin C applied in severe patients was 162.7 (71.1-328.6) $\mathrm{mg} / \mathrm{kg}$ (body weight)/day and $178.6(133.3-350.6) \mathrm{mg} / \mathrm{kg} /$ day in critical patients. The elevation of serum C-reactive protein was observed in both severe $(59.01 \pm 37.9 \mathrm{mg} / \mathrm{mL})$ and critical $(92.5 \pm 41.21 \mathrm{mg} / \mathrm{mL})$ and was decreased continuously at day $3(12.36 \pm 22.12 \mathrm{mg} / \mathrm{mL})$ and day $7(8.95 \pm 20.4 \mathrm{mg} / \mathrm{mL})$ in severe patients. For critical patients the dose was decreased at day $3(33.9 \pm 30.2 \mathrm{mg} / \mathrm{mL})$ and slightly increased at day $7(59.56 \pm 41.4 \mathrm{mg} / \mathrm{mL})[259]$.

Other antioxidant compounds that have been proposed as potential adjuvants in COVID-19 are zinc [260], selenium [261], melatonin [262], curcumin [263], N-acetylcystein [264,265], GC4419, a SOD mimetic [266], colchicine [267], $\alpha$-lipoic acid [268], glutathione [269], broccoli or glucoraphanin capsules [270], dypiridamole [271], cannabidiol [272], combinations of vitamin D, magnesium, and vitamin B12 [273], and diammonium glycyrrhizinate with vitamin C [274].

Currently, some studies propose the use of antioxidants to treat neurological manifestations of COVID-19, such as melatonin. Melatonin is a neurohormone produced and secreted from the pineal gland; it is distributed to different brain structures by CSF and it has been reported to act as protectant for neurons and glia. In a recent review, Wongchitrat and coworkers suggested the use of melatonin supplementation against SARS-CoV-2 infection due to its antioxidants, anti-apoptotic, immunomodulatory, and anti-inflammatory effects. The melatonin anti-inflammatory effect has been related to the activation of different cellular pathways; Sirtulin-1 activation by melatonin inhibits macrophage polarization into pro-inflammatory phenotype. Melatonin also suppresses NF-kB activation, stimulates Nrf2 production, reduces pro-inflammatory cytokines (TNF-a, IL-1, IL-6, IL-8, IL-17), and increases levels of anti-inflammatory cytokines (IL-10). The therapeutic use of melatonin has been proposed for brain injury such as hypoxia/ischemia/stroke and during viral infections, and melatonin antiviral effects in vitro include a decrease in virus titer both in supernatant and cells. Studies in animal models demonstrate its impact in the reduction of NO and malondyaldehyde (MDA) levels as well as inducible nitric oxide synthase (iNOS) activity and apoptotic cell death during viral infections. Meningitis/encephalitis, Guillain-Barré syndrome, and hypoxic ischemia/stroke associated with SARS-CoV-2 are proposed to be treated with adequate levels of melatonin [262]. Cardinali and coworkers 
also propose the use of melatonin as an adjuvant for anti-SARS-CoV-2 infection treatment; the authors report that it can improve the cognitive decay observed in COVID-19 patients and during vaccination it could increase $\operatorname{IgG}$ antibody response and the number of CD8+ T cells [275].

Other antioxidant compounds proposed as potential neuroprotectants for handling neuronal injury and inflammation during COVID-19 are the phytochemicals resveratrol, quercetin, and kaempferol. Resveratrol has shown a capacity for inducing autophagy by AMPK/SIRT1 activation and PI3K/AKT/mTORC1/2 inhibition, which has been related to rescue of Nf2. Inhibition of immunoproteasome by resveratrol has also been associated with autophagy activation and prevention of PTEN degradation as well as the inhibition of NF-kB, Nod-like receptor pyrin containing (NLRPC) inflammasome, and pro-inflammatory cytokines, whose upregulation has been associated with brain injury during subarachnoid hemorrhage and neuroinflammation [276]. Quercetin and kaempferol, in addition to having antioxidant properties, are anti-inflammatory compounds acting by autophagy induction through NLRP3 inhibition and enhancement of IL-1 secretion mainly in microglial cells [277]. These effects results in diminution of oxidative stress and neuroinflammation, M2 microglia polarization, preservation of BBB function and activation of AMPK and Nrf2 in brain tissue.

Barré and coworkers proposed that Montelukast, a cysteinyl leukotriene receptor antagonist used as an anti-inflammatory agent in acute asthma, can be a potent neuroprotector in COVID-19 patients due to its capacity to limit BBB damage and anticonvulsant properties in epilepsy models as well as the improvement of recovery after brain ischemia through its effects on oligodendrocytes precursor cells. Plus, it has been demonstrated that Montelukast can reduce neuroinflammation and induce neurogenesis by GPR17 receptor. Several studies showed that Montelukast can mitigate cytokine storms and reduce interaction between SARS-CoV-2 and ACE2, as well as increase mitochondrial mass and function at systemic level [278].

$\mathrm{HEMO}_{2}$ Life $^{\circledR}$ (M101) is an extracellular hemoglobin from the lugworm Arenicola marina with an oxygen capacity 40 times higher than the $\mathrm{HbA}$ of vertebrates, and it possesses anti-oxidative properties due to a superoxide dismutase activity-like based on copper and zinc. In animal models it showed an improvement of brain tissue oxygenation with $\mathrm{HEMO}_{2} \mathrm{Life}^{\circledR}$ (M101). Lupon and coworkers proposed its use for hypoxemia and post-hypoxic leuko-encephalopathy presented in patients with COVID-19 [279].

In a screening of Ayurvedic products with the potential to modulate the immune system, Maurya and coworkers used the swissADME web tool to show that some molecules with antiviral, anti-inflammatory, and antioxidant properties such as nimbin, piperine, thebaine, berberine, andrographolide, zingiberene, citronellol, and eugenol have high affinity with the SARS-CoV-2 spike protein as well as good BBB diffusion, suggesting their potential use as neuroprotective agents in COVID-19 patients [280].

Koh and coworkers proposed the use of ergothioneine, a natural antioxidant found in non-yeast fungi and some bacteria, as a possible nutraceutical COVID-19-related neurologic complication. In some in vitro studies it has been shown that this compound is a powerful scavenger of hydroxyl radicals, hypochlorous acid, and peroxynitrite that can act as an antioxidant and cytoprotective and have a good penetration of the BBB. The authors also reported that ergothioneine protects against the damage induced by $7 \mathrm{KC}$ in brain endothelial cells [281,282].

Kempuraj and coworkers reviewed the neuroprotective effects in neurotrauma and neurodegeneration of flavone luteolin by inhibition of hydrogen peroxide, nitric oxide, and malondialdehyde and normalization of the activities of acetylcholinesterase, glutathione S-transferase, and superoxide dismutase and improvement of the neuroinflammatory responses in experimental models of neurotrauma. Additionally, some reports showed that luteolin can suppress neuroinflammatory response, activation of microglia and astrocytes, oxidative stress, neuroinflammation, and the severity of neuroinflammatory diseases such as Alzheimer's disease, Parkinson's disease, multiple sclerosis, and TBI pathogenesis. More 
recently it has been employed as a suppressor of neuroinflammatory response in COVID19 patients, mainly because of its antiviral properties against SARS-CoV-2 by preventing the entry of the virus into the host cells and inhibition of TNF- $\alpha$, IL- $1 \beta$, IL-6, superoxide dismutase, and glutathione peroxidase, and its activation of microglia and astrocytes in neuroinflammatory conditions [283-285].

Ribeiro and collaborators proposed the use of P2X7 receptor antagonists for the prevention of neurological complications in COVID-19 patients. The hyperactivation of P2X7 receptors, ATP-gated ion channels expressed in the central nervous system, has been related to the inflammatory response induced by inflammasome activation and neuroimmune response activation, reactive oxygen species formation and glutamate release. The authors postulate that neuroinvasion of SARS-CoV-2 through the BBB observed in COVID-19 infection induces neuroinflammation mediated by hyperactivation of the P2X7 receptor and is associated with psychiatric disorders and neurodegeneration observed in this disease [286].

Uckun and collaborators proposed the use of Rejuveinix (RJX) as a neuroprotective agent in sepsis caused by COVID-19 infection. RJX is composed of natural antioxidants and anti-inflammatory agents that include ascorbic acid, magnesium sulfate heptahydrate, cyanocobalamin, thiamine hydrochloride, riboflavin $5^{\prime}$ phosphate, niacinamide, pyridoxine hydrochloride, and calcium D-pantothenate. The authors reported the capacity of RJX to improve the survival outcome of animals with lypopolisaccharide-galactosamine (LPS-GalN)-induced fatal sepsis caused by oxidative stress. The administration of RJX diminished the lipoperoxidation levels and normalized the levels of superoxide dismutase, catalase, and glutathione peroxidase in the mouse brain. According to these observations the authors propose the use of RJX in fatal sepsis and multi-organ failure observed in some patients infected with SARS-CoV-2 [287].

Other proposed candidates as neuroprotectors in patients with COVID-19 for their antioxidant capacity are: salicyl-carnosine [288], molecular hydrogen [224], cannabinoid type-2 receptor-selective agonists [289], propolis [290], thymoquinone, nigellidine, and $\alpha$-hederin [291], agomelatine [292], and ozone [293].

Regarding the use of antioxidants for the treatment of neurological or psychiatric manifestations in COVID-19 patients to improve prognosis, Sher and coworkers showed that the use of melatonin improved a case of delirium related to COVID-19 in a case of a healthy woman aged 70, diagnosed with COVID-19 by PCR for SARS-CoV-2, treated with ceftriaxone, azithromycin, and remdesivir and intubated for hypoxic respiratory failure and extubated 26 days later. Three days after, the patient was diagnosed with delirium and treated with melatonin ( $15 \mathrm{mg}$ per night) to regulate the sleep cycle and for its antioxidant and anti-inflammatory properties, concomitant with suvorexant (20 mg per night), guanfacine ( $0.5 \mathrm{mg}$ from $0.5 \mathrm{mg}$ per night titrated at $1 \mathrm{mg}$ three times daily), valproic acid (1250 mg per day), quetiapine (initially titrated at $250 \mathrm{mg}$ distributed throughout the day, but discontinued due to ineffectiveness), and haloperidol (8 $\mathrm{mg}$ per day). Although the patient had medical complications associated with lung damage from COVID-19, there was no evidence of delirium 10 days after treatment [161].

Olagnier and coworkers showed that SARS-CoV-2 infection induces the expression of genes related to inflammatory and antiviral pathways, including RIG-I receptor and Toll-like receptor signaling, in lung biopsies of COVID-19 patients as well as epithelial and kidney cell lines, and in genes associated to Nrf2 antioxidant response the expression is decreased. Using an in vitro approach, they explored the effects of the Nrf2 agonist dimethyl fumarate (DMF), a drug approved by the FDA for use as anti-inflammatory therapy for multiple sclerosis, and 4-octyl-itaconate (4-OI), a chemically synthesized, cellpermeable derivative of itaconate. Both compounds showed stimulation of antioxidant gene expression via Nrf2 induction in epithelial and kidney cell lines as well as primary human airway epithelial (HAE) cultures. Treatment with both agonists before SARS-CoV-2 cell infection reduced viral replication, the release of progeny, and cytotoxicity of SARSCoV-2. The genetic activation of Nrf2 using siRNA silencing of KEAP1 (inhibitor of Nrfr2) 
led to the restriction of SARS-CoV-2 replication, confirming that DMF and 4-OI have antiviral properties by Nrf2 activation. The study showed that 4-OI had morphological activity without loss of cell viability. The activity of 4-OI did not seem to overlap with other compounds known to perturb cell morphology, including rapamycin, bafilomycin, tunicamycin, cyclohexamide, emetine, mitomycin, or doxorubicin. There was no observable overlap with the activity profile of remdesivir or hydroxychloroquine, indicating that the antiviral mode of action of 4-OI is distinct from other known antiviral mechanisms. The authors also demonstrate that 4-OI and DMF prevent inflammatory cytokine gene expression induced by SARS-CoV-2 such as IFNB1, C-X-C motif chemokine 10 (CXCL10), TNFA, IL-1B, and C-C chemokine ligand 5 (CCL5) genes and increase Nrf2 inducible gene HMOX1. In addition, the effect of 4-OI on peripheral blood mononuclear cells (PBMC) from healthy donors and COVID-19 patients were examined. 4-OI treatment reduced CXCL10 mRNA and reduced the induction of IFN and IFN genes in response to RIG-I agonist (M8), inhibiting interferon regulatory factor 3 (IRF3) dimerization. IRF3 inhibition has been associated with Nrf2 expression since its silencing is enough to restore IRF3 dimerization and limit the effect of 4-OI. The authors propose the use of DMF and 4-OI as Nrf2 agonists that can be used to inhibit SARS-CoV-2 replication as well as the expression of associated inflammatory genes in patients with COVID-19 [198].

Currently, the effect of several antioxidant compounds for the treatment of neurological or psychiatric manifestation in COVID-19 patients is under evaluation in clinical trials (see Table 3).

Table 3. Current clinical trials evaluating the effect of antioxidant compounds on neurological manifestations in COVID-19.

\begin{tabular}{|c|c|c|c|}
\hline Antioxidant(s) & Protocol & & rological or Psychiatric Conditions Assessed \\
\hline Vitamin C & $\begin{array}{l}\text { Bolus doses of } 50 \mathrm{mg} / \mathrm{kg} \text { in } 50-\mathrm{mL} \text { of either } \\
\text { dextrose } 5 \% \text { in water or normal saline for } 30 \\
\text { to } 60 \mathrm{~min} \text {, every } 6 \mathrm{~h} \text { for } 96 \mathrm{~h}(200 \mathrm{mg} / \mathrm{kg} / \text { day } \\
\text { and } 16 \text { doses in total })(\mathrm{N}=800, \text { protocol } \\
\text { in recruiting) }\end{array}$ & 0 & $\begin{array}{l}\text { Pain, discomfort, anxiety / depression, } \\
\text { mobility (by } 6 \text { months) and consciousness } \\
\text { (up to } 28 \text { days) }\end{array}$ \\
\hline \multirow{4}{*}{ Zinc and vitamin $C$} & $\begin{array}{l}\text { - Standard treatment }+220 \mathrm{mg} \text { (zinc) and } 1 \mathrm{~g} \\
\text { (vitamin } \mathrm{C}) / 24 \mathrm{~h} / 10 \text { days }(\mathrm{N}=50 \text {, protocol } \\
\text { not yet recruiting) }\end{array}$ & O & $\begin{array}{l}\text { Muscle or body aches, headache, loss of taste, } \\
\text { loss of smell by } 28 \text { days }\end{array}$ \\
\hline & $\begin{array}{l}\text { - Standard treatment }+8000 \mathrm{mg} \text { (vitamin C) } \\
\text { divided into } 2-3 \text { doses/day with food and } \\
50 \mathrm{mg} \text { (zinc gluconate) daily at bedtime } \\
(\mathrm{N}=520, \text { protocol in recruiting) }\end{array}$ & $\bigcirc$ & $\begin{array}{l}\text { Headache, loss of taste, loss of smell } \\
\text { by } 28 \text { days }\end{array}$ \\
\hline & $\begin{array}{l}80 \mathrm{mg} \text { (zinc) } / 500 \mathrm{mg} \text { (vitamin C) daily for } \\
42 \text { days additional to hydroxychloroquine, } \\
\text { ivermectin, and povidone iodine treatment } \\
(\mathrm{N}=4257, \text { protocol completed) }\end{array}$ & O & Change in smell by 42 days \\
\hline & $\begin{array}{l}\text { Standard treatment }+8000 \mathrm{mg} \text { (zinc) divided } \\
\text { into } 2-3 \text { doses / day with food and } 50 \mathrm{mg} \\
\text { (zinc gluconate) daily at bedtime }(\mathrm{N}=214, \\
\text { protocol with recruitment completed) }\end{array}$ & $\bigcirc$ & $\begin{array}{l}\text { Muscle and body aches, headache, new loss } \\
\text { of taste and new loss of smell by } 28 \text { days }\end{array}$ \\
\hline $\begin{array}{l}\text { Hydroxychloroquine, } \\
\text { vitamin C, vitamin D, } \\
\text { and zinc }\end{array}$ & $\begin{array}{l}\text { - Treatment with hydroxychloroquine will last } \\
1 \text { day. Treatment with vitamin } \mathrm{C} \text {, vitamin } \mathrm{D} \text {, } \\
\text { and zinc will last } 12 \text { weeks }(\mathrm{N}=600 \text {, protocol } \\
\text { in recruiting) }\end{array}$ & $\bigcirc$ & $\begin{array}{l}\text { Headache and difficulty speaking } \\
\text { by } 24 \text { weeks }\end{array}$ \\
\hline Melatonin & $\begin{array}{l}\text { - Oral } 10 \mathrm{mg} / \text { three times a day for } 14 \text { days } \\
(\mathrm{N}=30 \text {, protocol in recruiting) }\end{array}$ & $\bigcirc$ & $\begin{array}{l}\text { Headache, loss of taste, loss of smell and } \\
\text { dizziness by } 28 \text { days }\end{array}$ \\
\hline
\end{tabular}


Table 3. Cont.

\begin{tabular}{|c|c|c|}
\hline Antioxidant(s) & Protocol & Neurological or Psychiatric Conditions Assessed \\
\hline $\begin{array}{c}\text { Glycine and } \\
\text { N-acetylcysteine }\end{array}$ & $\begin{array}{l}\text { - Supplementation by } 2 \text { weeks }(\mathrm{N}=64 \text {, } \\
\text { protocol in recruiting) }\end{array}$ & $\begin{array}{l}\text { Change in cognition and memory assessed } \\
\text { up to } 10 \text { weeks }\end{array}$ \\
\hline Glycine & $\begin{array}{l}\text { - Habitual treatment }+0.5 \mathrm{~g} / \mathrm{kg} / \text { day by } \\
\text { nasogastric tube } / 4 \text { equal doses per day } \\
(\mathrm{N}=82, \text { protocol in recruiting })\end{array}$ & Consciousness assessed up to 12 months \\
\hline $\begin{array}{l}\text { Vitamin C, vitamin E, } \\
\text { melatonin, and } \\
\text { N-acetylcysteine }\end{array}$ & $\begin{array}{l}\text { One antioxidant plus pentoxifylline. } \\
\text { Vitamin C } 1 \mathrm{~g} / 12 \mathrm{~h} \text {. Vitamin E } 800 \mathrm{mg} / 24 \mathrm{~h} \text {. } \\
\text { Melatonin } 50 \mathrm{mg} / 24 \mathrm{~h} \text {. N-acetylcysteine } \\
600 \mathrm{mg} / 12 \mathrm{~h}(\mathrm{~N}=11 \text {, protocol active } \\
\text { not recruiting) }\end{array}$ & $\begin{array}{l}\text { Consciousness for } 7 \text { days post } \\
\text { antioxidant dose }\end{array}$ \\
\hline Previfenon ${ }^{\circledR}$ & $\begin{array}{l}\text { - Contains } 250 \mathrm{mg} \text { of } \\
\text { epigallocatechin-3-gallate (EGCG). Total } \\
\text { EGCG dose per patient will be } 750 \mathrm{mg} / \text { day } \\
\text { ( } 3 \text { capsules } / 8 \mathrm{~h} \text { ) for } 40 \text { consecutive days } \\
\text { (variable time between } 60 \text { and } 70 \text { days }) \\
(\mathrm{N}=524 \text {, protocol in recruiting) }\end{array}$ & $\begin{array}{l}\text { Myalgia, loss of smell, loss of taste, headache } \\
\text { by } 40-70 \text { days of intervention }\end{array}$ \\
\hline $\begin{array}{l}\text { Hesperidin and } \\
\text { diosmin }\end{array}$ & $\begin{array}{l}\text { - } 1000 \mathrm{mg} / 8 \mathrm{~h} \text { for } 7 \text { days and } 1000 \mathrm{mg} / 12 \mathrm{~h} \\
\text { times daily for } 3 \text { days }(\mathrm{N}=100 \text {, protocol not } \\
\text { yet recruiting) }\end{array}$ & Myalgia by 14 days \\
\hline $\begin{array}{l}\text { Fuzheng Huayu Tablet } \\
\text { (FZHY) and vitamin C }\end{array}$ & $\begin{array}{l}\text { - FZHY tablet administration: } 0.4 \mathrm{~g} / \text { tablet, } \\
1.6 \mathrm{~g} \text { /time, three times/day, medicine to be } \\
\text { taken after meals. Vitamin C tablets } \\
\text { administration: } 0.2 \mathrm{~g} / \text { time, three times / day. } \\
(\mathrm{N}=160 \text {, protocol in recruiting })\end{array}$ & Insomnia by 24 weeks \\
\hline Resveratrol & $\begin{array}{l}\text { - Capsules of } 1.0 \mathrm{~g} \text {, orally once a day for six } \\
\text { months. }(\mathrm{N}=30 \text {, protocol not yet } \\
\text { in recruiting) }\end{array}$ & Depression by 9 months \\
\hline
\end{tabular}

www.clinicaltrials.gov, accessed on 22 April 2021 [294].

\section{Perspectives}

The current state of emergency due to the contingency derived from the COVID-19 pandemic has opened a wide range of questions, some of them with a response derived from the effort of the international scientific community, others in the process of being answered and others that will remain to be answered in the future. The reality of this disease caused by the SARS-CoV-2 virus has led us to understand that we are in the process of knowing both its clinical manifestations and its comorbidities, but above all its sequelae, the need to categorize depending on the age group, and the type of population affected, among so many other questions that make us think that this is only the beginning. We are in the first stages of understanding this disease since its worldwide recognition in December 2019, and therefore we need to keep monitoring COVID-19 to understand its implications and its effect on the chronicity of the symptoms and sequelae. This has led to a search for new therapeutic strategies that treat the acute symptoms of this disease and at the same time, we must consider how these strategies can impact the management of the sequelae. We must consider that this type of infection generates pro-inflammatory processes at the systemic and central level, which is why powerful pharmacological tools are required to address these alterations and their possible consequences, always taking into account avoiding unwanted, adverse effects.

We must point out that, although the damages generated at the systemic level are serious, at the neurological level they are not to be disregarded. The degrees of disability that can be generated are still in the process of being evaluated and the need to have 
therapeutic alternatives for the future is crucial. Treating and hypothesizing the possible mechanisms generated during this type of infection that can lead to these sequelae has become one of the main objectives in managing this pathology.

In particular, the use of antioxidant agents for the management of neurological diseases where an oxidative stress state occurs has been well received; this will allow us to transfer the knowledge and determine if these strategies can be used in the neurological alterations that are being reported and are attributed to SARS-CoV-2 infection. Currently, there is scientific evidence that these antioxidants can also act as anti-inflammatories which has led us to consider these therapeutic agents as having great potential for the management of this disease, considering that the most serious states of the disease are attributed to exacerbated pro-inflammatory states. This is in consideration of the mechanism known as cytokine storm, which has been reported in various age groups and in different populations, both with and without previous chronic diseases.

It is worth mentioning that although different antioxidant substances that can be used for this purpose have been brought to light, the road is still long, and it is the task of the scientific community to continue with the studies in order to find the best therapeutic strategy for the management of COVID-19 without leaving behind the efforts in the research fields related to the generation of vaccines, as well as drugs with other characteristics that are focused in the treatment of symptoms, and comorbidities and sequelae both at a systemic and neurological level attributed to this type of infection.

\section{Conclusions}

It is imperative to continue with the study of the mechanisms that underlie $\mathrm{CoV}$ infections to gain understanding at different levels from genes to clinical practice; this will allow us to find the therapeutic targets that can be used for their management, particularly the substances that present antioxidant and anti-inflammatory activity which have already been reported to be effective in the treatment of other neurological diseases. Subsequent studies should be considered to establish the real effect both in the management of clinical symptoms and comorbidities, and on the sequelae (yet to be determined) derived from the damage presented by SARS-CoV-2 infection. Emphasis should be placed on establishing these measures according to the age group and the characteristics of the population affected by this disease.

Author Contributions: Conceptualization, N.C.-R. and C.B.; Investigation, N.C.-R., C.B., A.V.-C., I.I.-M., S.G.-M., E.Y.H.-C., J.P.-C., L.C.-A. and B.H.-O.; Writing-Original Draft Preparation, N.C.-R. and C.B.; Writing-Review and Editing, N.C.-R., C.B., A.V.-C., I.I.-M., S.G.-M., E.Y.H.-C., J.P.-C. L.C.-A. and B.H.-O.; Supervision, N.C.-R. All authors have read and agreed to the published version of the manuscript.

Funding: This research received no external funding.

Acknowledgments: We appreciate the support of the E022 Program of the Instituto Nacional de Pediatría (protocols 041/2018 and 031/2018) and from SNI-CONACYT fellow (N.C.-R., C.B., A.V.-C., S.G.-M., J.P.-C. and L.C.-A.)

Conflicts of Interest: The authors declare no conflict of interest.

\section{References}

1. World Health Organization. WHO Coronavirus (COVID-19) Dashboard. Available online: https://covid19.who.int/ (accessed on 22 April 2021).

2. Koyama, T.; Platt, D.; Parida, L. Variant analysis of SARS-cov-2 genomes. Bull. WHO 2020, 98, 495-504. [CrossRef]

3. Ou, X.; Liu, Y.; Lei, X.; Li, P.; Mi, D.; Ren, L.; Guo, L.; Guo, R.; Chen, T.; Hu, J.; et al. Characterization of spike glycoprotein of SARS-CoV-2 on virus entry and its immune cross-reactivity with SARS-CoV. Nat. Commun. 2020, 11, 1620. [CrossRef]

4. Dömling, A.; Gao, L. Chemistry and biology of SARS-CoV-2. Inside Chem. 2020, 6, 1283-1295. [CrossRef]

5. Day, T.; Gandon, S.; Lion, S.; Otto, S.P. On the evolutionary epidemiology of SARS-CoV-2. Curr Biol. 2020, 30, R849-R857. [CrossRef] [PubMed] 
6. Lou, J.J.; Movassaghi, M.; Gordy, D.; Olson, M.G.; Zhang, T.; Khurana, M.S.; Chen, Z.; Perez-Rosendahl, M.; Thammachantha, S.; Singer, E.J.; et al. Neuropathology of COVID-19 (neuro-COVID): Clinicopathological update. Free Neuropathol. 2021, 18, 2. [CrossRef]

7. Volz, E.; Hill, V.; McCrone, J.T.; Price, A.; Jorgensen, D.; O’Toole, Á.; Southgate, J.; Johnson, R.; Jackson, B.; Nascimento, F.F.; et al. Evaluating the Effects of SARS-CoV-2 Spike Mutation D614G on Transmissibility and Pathogenicity. Cell 2021, 7, 64-75.e11. [CrossRef] [PubMed]

8. Naqvi, A.A.T.; Fatima, K.; Mohammad, T.; Fatima, U.; Singh, I.K.; Singh, A.; Atif, S.M.; Hariprasad, G.; Hasan, G.M.; Hassan, M.I. Insights into SARS-CoV-2 genome, structure, evolution, pathogenesis and therapies: Structural genomics approach. Biochim. Biophys. Acta Mol Basis Dis. 2020, 866, 165878. [CrossRef] [PubMed]

9. Morawska, L.; Cao, J. Airborne transmission of SARS-CoV-2: The world should face the reality. Environ. Int. 2020, 139, 105730. [CrossRef]

10. Ai, T.; Yang, Z.; Hou, H.; Zhan, C.; Chen, C.; Lv, W.; Tao, Q.; Sun, Z.; Xia, L. Correlation of Chest CT and RT-PCR Testing for Coronavirus Disease 2019 (COVID-19) in China: A Report of 1014 Cases. Radiology 2020, 296, E32-E40. [CrossRef]

11. Zhang, J.; Wang, M.; Zhao, M.; Guo, S.; Xu, Y.; Ye, J.; Ding, W.; Wang, Z.; Ye, D.; Pan, W.; et al. The Clinical Characteristics and Prognosis Factors of Mild-Moderate Patients With COVID-19 in a Mobile Cabin Hospital: A Retrospective, Single-Center Study. Front. Public Health 2020, 5, 264. [CrossRef]

12. Li, Q.; Guan, X.; Wu, P.; Wang, X.; Zhou, L.; Tong, Y.; Ren, R.; Leung, K.S.M.; Lau, E.H.Y.; Wong, J.Y.; et al. Early Transmission Dynamics in Wuhan, China, of Novel Coronavirus-Infected Pneumonia. N. Engl. J. Med. 2020, 382, 1199-1207. [CrossRef] [PubMed]

13. Hui, D.S.; Azhar, E.; Madani, T.A.; Ntoumi, F.; Kock, R.; Dar, O.; Ippolito, G.; Mchugh, T.D.; Memish, Z.A.; Drosten, C.; et al. The continuing 2019-nCoV epidemic threat of novel coronaviruses to global health-The latest 2019 novel coronavirus outbreak in Wuhan, China. Int. J. Infect. Dis. 2020, 91, 264-266. [CrossRef] [PubMed]

14. Chen, N.; Zhou, M.; Dong, X.; Qu, J.; Gong, F.; Han, Y.; Qiu, Y.; Wang, J.; Liu, Y.; Wei, Y.; et al. Epidemiological and clinical characteristics of 99 cases of 2019 novel coronavirus pneumonia in Wuhan, China: A descriptive study. Lancet 2020, 395, 507-513. [CrossRef]

15. Pajo, A.T.; Espiritu, A.I.; Apor, A.; Jamora, R.D.G. Neuropathologic findings of patients with COVID-19: A systematic review. Neurol. Sci. 2021, 42, 1255-1266. [CrossRef]

16. Domingues, R.B.; Mendes-Correa, M.C.; de Moura Leite, F.B.V.; Sabino, E.C.; Salarini, D.Z.; Claro, I.; Santos, D.W.; de Jesus, J.G.; Ferreira, N.E.; Romano, C.M.; et al. First case of SARS-COV-2 sequencing in cerebrospinal fluid of a patient with suspected demyelinating disease. J. Neurol. 2020, 267, 3154-3156. [CrossRef] [PubMed]

17. Cheng, Q.; Yang, Y.; Gao, J. Infectivity of human coronavirus in the brain. EBioMedicine 2020, 56, 102799. [CrossRef]

18. Guedj, E.; Million, M.; Dudouet, P.; Tissot-Dupont, H.; Bregeon, F.; Cammilleri, S.; Raoult, D. ${ }^{18}$ F-FDG brain PET hypometabolism in post-SARS-CoV-2 infection: Substrate for persistent/delayed disorders? Eur. J. Nucl. Med. Mol. Imaging. 2021, 48, 592-595. [CrossRef]

19. Pellegrini, L.; Albecka, A.; Mallery, D.L.; Kellner, M.J.; Paul, D.; Carter, A.P.; James, L.C.; Lancaster, M.A. SARS-CoV-2 Infects the Brain Choroid Plexus and Disrupts the Blood-CSF Barrier in Human Brain Organoids. Cell Stem. Cell 2020, 3 , 951-961.e5. [CrossRef]

20. Politi, L.S.; Salsano, E.; Grimaldi, M. Magnetic Resonance Imaging Alteration of the Brain in a Patient with Coronavirus Disease 2019 (COVID-19) and Anosmia. JAMA Neurol. 2020, 77, 1028-1029. [CrossRef]

21. Bougakov, D.; Podell, K.; Goldberg, E. Multiple Neuroinvasive Pathways in COVID-19. Mol. Neurobiol. 2021, 58, 564-575. [CrossRef]

22. Dubé, M.; Le Coupanec, A.; Wong, A.H.M.; Rini, J.M.; Desforges, M.; Talbot, P.J. Axonal Transport Enables Neuron-to-Neuron Propagation of Human Coronavirus OC43. J. Virol. 2018, 92, e00404-18. [CrossRef]

23. Abboud, H.; Abboud, F.Z.; Kharbouch, H.; Arkha, Y.; El Abbadi, N.; El Ouahabi, A. COVID-19 and SARS-Cov-2 Infection: Pathophysiology and Clinical Effects on the Nervous System. World Neurosurg. 2020, 140, 49-53. [CrossRef]

24. Miyazawa, M. Immunopathogenesis of SARS-CoV-2-induced pneumonia: Lessons from influenza virus infection. Inflamm. Regen. 2020, 40, 39. [CrossRef] [PubMed]

25. Kantonen, J.; Mahzabin, S.; Mäyränpää, M.I.; Tynninen, O.; Paetau, A.; Andersson, N.; Sajantila, A.; Vapalahti, O.; Carpén, O.; Kekäläinen, E.; et al. Neuropathologic features of four autopsied COVID-19 patients. Brain Pathol. 2020, 30, 1012-1016. [CrossRef] [PubMed]

26. Zhai, P.; Ding, Y.; Li, Y. The impact of COVID-19 on ischemic stroke. Diagn. Pathol. 2020, 15, 78. [CrossRef] [PubMed]

27. Letko, M.; Marzi, A.; Munster, V. Functional assessment of cell entry and receptor usage for SARS-CoV-2 and other lineage B betacoronaviruses. Nat. Microbiol. 2020, 5, 562-569. [CrossRef]

28. Fu, J.; Zhang, J.; Gong, Y.; Testa, C.L.; Klein-Szanto, A.J. Regulation of HIF-1 alpha by the proprotein convertases furin and PC7 in human squamous carcinoma cells. Mol. Carcinog. 2015, 54, 698-706. [CrossRef]

29. Chauhan, A.; Kaur, R.; Chakrbarti, P.; Pal, A. "Silent Hypoxemia" Leads to Vicious Cycle of Infection, Coagulopathy and Cytokine Storm in COVID-19: Can Prophylactic Oxygen Therapy Prevent It? Indian J. Clin. Biochem. 2021, 15, 1-5. [CrossRef]

30. Haga, S.; Yamamoto, N.; Nakai-Murakami, C.; Osawa, Y.; Tokunaga, K.; Sata, T.; Yamamoto, N.; Sasazuki, T.; Ishizaka, Y. Modulation of TNF-alpha-converting enzyme by the spike protein of SARS-CoV and ACE2 induces TNF-alpha production and facilitates viral entry. Proc. Natl. Acad. Sci. USA 2008, 105, 7809-7814. [CrossRef] 
31. Wu, D.; Yang, X.O. TH17 responses in cytokine storm of COVID-19: An emerging target of JAK2 inhibitor Fedratinib. J. Microbiol. Immunol. Infect. 2020, 53, 368-370. [CrossRef]

32. Sun, S.H.; Chen, Q.; Gu, H.J.; Yang, G.; Wang, Y.X.; Huang, X.Y.; Liu, S.S.; Zhang, N.N.; Li, X.F.; Xiong, R.; et al. A Mouse Model of SARS-CoV-2 Infection and Pathogenesis. Cell Host Microbe 2020, 28, 124-133.e4. [CrossRef]

33. Wang, J.; Jiang, M.; Chen, X.; Montaner, L.J. Cytokine storm and leukocyte changes in mild versus severe SARS-CoV-2 infection: Review of 3939 COVID-19 patients in China and emerging pathogenesis and therapy concepts. J. Leukoc. Biol. 2020, 108, 17-41. [CrossRef]

34. Shenoy, S. Coronavirus (Covid-19) sepsis: Revisiting mitochondrial dysfunction in pathogenesis, aging, inflammation, and mortality. Inflamm. Res. 2020, 69, 1077-1085. [CrossRef] [PubMed]

35. Nagu, P.; Parashar, A.; Behl, T.; Mehta, V. CNS implications of COVID-19: A comprehensive review. Rev. Neurosci. 2020, 32, 219-234. [CrossRef]

36. Chen, K.H.; Wang, S.F.; Wang, S.Y.; Yang, Y.-P.; Wang, M.-L.; Chiou, S.-H.; Chang, Y.-L. Pharmacological development of the potential adjuvant therapeutic agents against coronavirus disease 2019. J Chin. Med. Assoc. 2020, 10, 1097. [CrossRef]

37. Lan, J.; Ge, J.; Yu, J.; Shan, S.; Zhou, H.; Fan, S.; Zhang, Q.; Shi, X.; Wang, Q.; Zhang, L.; et al. Structure of the SARS-CoV-2 spike receptor-binding domain bound to the ACE2 receptor. Nature 2020, 581, 215-220. [CrossRef] [PubMed]

38. Belouzard, S.; Chu, V.C.; Whittaker, G.R. Activation of the SARS coronavirus spike protein via sequential proteolytic cleavage at two distinct sites. Proc. Natl. Acad. Sci. USA 2009, 106, 5871-5876. [CrossRef]

39. Hoffmann, M.; Kleine-Weber, H.; Schroeder, S.; Krüger, N.; Herrler, T.; Erichsen, S.; Schiergens, T.S.; Herrler, G.; Wu, N.-H.; Nitsche, A.; et al. SARS-CoV-2 cell entry depends on ACE2 and TMPRSS2 and is blocked by a clinically proven protease inhibitor. Cell 2020, 181, 271-280. [CrossRef]

40. Rodrigues Prestes, T.R.; Rocha, N.P.; Miranda, A.S.; Teixeira, A.L.; Simoes-E-Silva, A.C. The Anti-Inflammatory Potential of ACE2/Angiotensin-(1-7)/Mas Receptor Axis: Evidence from Basic and Clinical Research. Curr. Drug. Targets. 2017, 18, 1301-1313. [CrossRef]

41. Bautista-Vargas, M.; Bonilla-Abadía, F.; Cañas, C.A. Potential role for tissue factor in the pathogenesis of hypercoagulability associated with in COVID-19. J. Thromb. Thrombolysis 2020, 1-5. [CrossRef]

42. Yan, R.; Zhang, Y.; Li, Y.; Xia, L.; Guo, Y.; Zhou, Q. Structural basis for the recognition of SARS-CoV-2 by full-length human ACE2. Science 2020, 367, 1444-1448. [CrossRef]

43. Mody, V.; Ho, J.; Wills, S.; Mawri, A.; Lawson, L.; Ebert, M.C.C.J.C.; Fortin, G.M.; Rayalam, S.; Taval, S. Identification of 3-chymotrypsin like protease (3CLPro) inhibitors as potential anti-SARS-CoV-2 agents. Commun. Biol. 2021, 4, 93. [CrossRef]

44. Lanza, K.; Perez, L.G.; Costa, L.B.; Cordeiro, T.M.; Palmeira, V.A.; Ribeiro, V.T.; Samoes e Silva, A.C. Covid-19: The reninangiotensin system imbalance hypothesis. Clin. Sci. 2020, 134, 1259-1264. [CrossRef]

45. Cantero-Navarro, E.; Fernández-Fernández, B.; Ramos, A.M.; Rayego-Mateos, S.; Rodrigues-Diez, R.R.; Sánchez-Niño, M.D.; Sanz, A.B.; Ruiz-Ortega, M.; Ortiz, A. Renin-angiotensin system and inflammation update. Mol. Cell. Endocrinol. 2021, 111254. [CrossRef]

46. Zhang, Y.Y.; Yu, Y.; Yu, C. Antifibrotic Roles of RAAS Blockers: Update. Adv. Exp. Med. Biol. 2019, 1165, 671-691. [CrossRef] [PubMed]

47. Hikmet, F.; Méar, L.; Edvinsson, Å.; Micke, P.; Uhlén, M.; Lindskog, C. The protein expression profile of ACE2 in human tissues. Mol. Syst. Biol. 2020, 16, e9610. [CrossRef]

48. Chen, R.; Wang, K.; Yu, J.; Howard, D.; French, L.; Chen, Z.; Wen, C.; Xu, Z. The Spatial and Cell-Type Distribution of SARS-CoV-2 Receptor ACE2 in the Human and Mouse Brains. Front. Neurol. 2021, 20, 573095. [CrossRef]

49. Dean, A.Q.; Bozza, W.P.; Twomey, J.D.; Luo, S.; Nalli, A.; Zhang, B. The fight against COVID-19: Striking a balance in the renin-angiotensin system. Drug. Discov. Today 2021. [CrossRef] [PubMed]

50. Martínez-Revelles, S.; Avendaño, M.S.; García-Redondo, A.B.; Alvarez, Y.; Aguado, A.; Pérez-Girón, J.V.; García-Redondo, L.; Esteban, V.; Redondo, J.M.; Alonso, M.J.; et al. Reciprocal relationship between reactive oxygen species and cyclooxygenase-2 and vascular dysfunction in hypertension. Antioxid. Redox. Signal. 2013, 18, 51-65. [CrossRef] [PubMed]

51. Vajapey, R.; Rini, D.; Walston, J.; Abadir, P. The impact of age-related dysregulation of the angiotensin system on mitochondrial redox balance. Front. Physiol. 2014, 5, 439. [CrossRef]

52. Tay, M.Z.; Poh, C.M.; Rénia, L.; MacAry, P.A.; Ng, L.F.P. The trinity of COVID-19: Immunity, inflammation and intervention. Nat. Rev. Immunol. 2020, 20, 363-374. [CrossRef] [PubMed]

53. Ruan, Q.; Yang, K.; Wang, W.; Jiang, L.; Song, J. Clinical predictors of mortality due to COVID-19 based on an analysis of data of 150 patients from Wuhan, China. Int. Care Med. 2020, 46, 846-848. [CrossRef] [PubMed]

54. Li, Y.C.; Bai, W.Z.; Hashikawa, T. The neuroinvasive potential of SARS-CoV2 may play a role in the respiratory failure of COVID-19 patients. J. Med. Virol. 2020, 92, 552-555. [CrossRef] [PubMed]

55. The Human Protein Atlas. Available online: https:/ / www.proteinatlas.org/ENSG00000197635-DPP4/tissue (accessed on 2 June 2021).

56. De Wit, E.; van Doremalen, N.; Falzarano, D.; Munster, V.J. SARS and MERS: Recent insights into emerging coronaviruses. Nat. Rev. Microbiol. 2016, 14, 523-534. [CrossRef]

57. Lukiw, W.J.; Pogue, A.; Hill, J.M. SARS-CoV-2 Infectivity and Neurological Targets in the Brain. Cell Mol. Neurobiol. 2020, 25, 1-8. [CrossRef] 
58. Pennisi, M.; Lanza, G.; Falzone, L.; Fisicaro, F.; Ferri, R.; Bella, R. SARS-CoV-2 and the Nervous System: From Clinical Features to Molecular Mechanisms. Int. J. Mol. Sci. 2020, 21, 5475. [CrossRef]

59. Kumari, P.; Rothan, H.A.; Natekar, J.P.; Stone, S.; Pathak, H.; Strate, P.G.; Arora, K.; Brinton, M.A.; Kumar, M. Neuroinvasion and Encephalitis Following Intranasal Inoculation of SARS-CoV-2 in K18-hACE2 Mice. Viruses 2021, 13, 132. [CrossRef]

60. El Bini Dhouib, I. Does coronaviruses induce neurodegenerative diseases? A systematic review on the neurotropism and neuroinvasion of SARS-CoV-2. Drug. Discov. Ther. 2021, 14, 262-272. [CrossRef]

61. Wu, Y.; Xu, X.; Chen, Z.; Duan, J.; Hashimoto, K.; Yang, L.; Liu, C.; Yang, C. Nervous system involvement after infection with COVID-19 and other coronaviruses. Brain. Behav. Immun. 2020, 87, 18-22. [CrossRef]

62. Toscano, G.; Palmerini, F.; Ravaglia, S.; Ruiz, L.; Invernizzi, P.; Cuzzoni, M.G.; Franciotta, D.; Baldanti, F.; Daturi, R.; Postorino, P.; et al. Guillain-Barré Syndrome Associated with SARS-CoV-2. N. Engl. J. Med. 2020, 382, 2574-2576. [CrossRef]

63. Kabbani, N.; Olds, J.L. Does COVID19 Infect the Brain? If So, Smokers Might Be at a Higher Risk. Mol. Pharmacol. 2020, 97, 351-353. [CrossRef]

64. Brann, D.; Tsukahara, T.; Weinreb, C.; Lipovsek, M.; Van den Berge, K.; Gong, B.; Chance, R.; Macaulay, I.; Chou, H.-J.; Fletcher, R.B.; et al. Non-neuronal expression of SARS-CoV-2 entry genes in the olfactory system suggests mechanisms underlying COVID-19-associated anosmia. Sci. Adv. 2020, 6, eabc5801. [CrossRef] [PubMed]

65. De Oliveira, F.A.A.; Palmeira, D.C.C.; Rocha-Filho, P.A.S. Headache and pleocytosis in CSF associated with COVID-19: Case report. Neurol. Sci. 2020, 11, 3021-3022. [CrossRef] [PubMed]

66. Ellul, M.A.; Benjamin, L.; Singh, B.; Lant, S.; Michael, B.D.; Easton, A.; Kneen, R.; Defres, S.; Sejvar, J.; Solomon, T. Neurological associations of COVID-19. Lancet Neurol. 2020, 9, 767-783. [CrossRef]

67. Suresh Kumar, V.C.; Mukherjee, S.; Harne, P.S.; Subedi, A.; Ganapathy, M.K.; Patthipati, V.S.; Sapkota, B. Novelty in the gut: A systematic review and meta-analysis of the gastrointestinal manifestations of COVID-19. BMJ Open Gastroenterol. 2020, 1, e000417. [CrossRef]

68. Lippi, A.; Domingues, R.; Setz, C.; Outeiro, T.F.; Krisko, A. SARS-CoV-2: At the Crossroad Between Aging and Neurodegeneration. Mov. Disord. 2020, 5, 716-720. [CrossRef]

69. Helms, J.; Kremer, S.; Merdji, H.; Clere-Jehl, R.; Schenck, M.; Kummerlen, C.; Collange, O.; Boulay, C.; Fafi-Kremer, S.; Ohana, M.; et al. Neurologic Features in Severe SARS-CoV-2 Infection. N. Engl. J. Med. 2020, 382, 2268-2270. [CrossRef] [PubMed]

70. Montalvan, V.; Lee, J.; Bueso, T.; De Toledo, J.; Rivas, K. Neurological manifestations of COVID-19 and other coronavirus infections: A systematic review. Clin. Neurol. Neurosurg. 2020, 194, 105921. [CrossRef]

71. Di Carlo, D.T.; Montemurro, N.; Petrella, G.; Siciliano, G.; Ceravolo, R.; Perrini, P. Exploring the clinical association between neurological symptoms and COVID-19 pandemic outbreak: A systematic review of current literature. J. Neurol. 2020, 268, 1561-1569. [CrossRef]

72. Mao, L.; Jin, H.; Wang, M.; Hu, Y.; Chen, S.; He, Q.; Chang, J.; Hong, C.; Zhou, Y.; Wang, D.; et al. Neurologic Manifestations of Hospitalized Patients with Coronavirus Disease 2019 in Wuhan, China. JAMA Neurol. 2020, 77, 683-690. [CrossRef]

73. Kholin, A.A.; Zavadenko, N.N.; Nesterovskiy, Y.E.; Kholina, E.A.; Zavadenko, A.N.; Khondkaryan, G.S. [Features of neurological manifestations of the COVID-19 in children and adults]. Zh. Nevrol. Psikhiatr. Im. S.S. Korsakova 2020, 120, 114-120. [CrossRef]

74. Nath, A.; Smith, B. Neurological complications of COVID-19: From bridesmaid to bride. Arq. Neuropsiquiatr. 2020, 78, 459-460. [CrossRef]

75. Fisicaro, F.; Di Napoli, M.; Liberto, A.; Fanella, M.; Di Stasio, F.; Pennisi, M.; Bella, R.; Lanza, G.; Mansueto, G. Neurological Sequelae in Patients with COVID-19: A Histopathological Perspective. Int. J. Environ. Res. Public Health 2021, 18, 1415. [CrossRef]

76. Abdelnaby, R.; Elsayed, M.; Abele-Haupts, F.; Barkin, M.E.; Rudek, M.A.; Schmidt, K. COVID-19 induced encephalopathy-A Case Report. Res. Sq. 2020. [CrossRef]

77. Abdi, S.; Ghorbani, A.; Fatehi, F. The association of SARS-CoV-2 infection and acute disseminated encephalomyelitis without prominent clinical pulmonary symptoms. J. Neurol. Sci. 2020, 416, 117001. [CrossRef]

78. Anzalone, N.; Castellano, A.; Scotti, R.; Scandroglio, A.M.; Filippi, M.; Ciceri, F.; Tresoldi, M.; Falini, A. Multifocal laminar cortical brain lesions: A consistent MRI finding in neuro-COVID-19 patients. J. Neurol. 2020, 267, 2806-2809. [CrossRef] [PubMed]

79. Conto-Palomino, N.M.; Cabrera-Bueno, M.L.; Vargas-Ponce, K.G.; Rondón-Abuhadba, E.A.; Atamari-Anahui, N. Encefalitis asociada a COVID-19 en una niña de 13 años: Reporte de caso [Encephalitis associated with COVID-19 in a 13-year-old girl: A case report]. Medwave 2020, 20, e7984. [CrossRef] [PubMed]

80. Delorme, C.; Paccoud, O.; Kas, A.; Hesters, A.; Bombois, S.; Shambrook, P.; Boullet, A.; Doukhi, D.; Le Guennec, L.; Godefroy, N.; et al. COVID-19-related encephalopathy: A case series with brain FDG-positron-emission tomography/computed tomography findings. Eur. J. Neurol. 2020, 27, 2651-2657. [CrossRef] [PubMed]

81. Espinosa, P.S.; Rizvi, Z.; Sharma, P.; Hindi, F.; Filatov, A. Neurological Complications of Coronavirus Disease (COVID-19): Encephalopathy, MRI Brain and Cerebrospinal Fluid Findings: Case 2. Cureus 2020, 12, e7930. [CrossRef]

82. Filatov, A.; Sharma, P.; Hindi, F.; Espinosa, P.S. Neurological Complications of Coronavirus Disease (COVID-19): Encephalopathy. Cureus 2020, 12, e7352. [CrossRef] [PubMed]

83. Freire-Álvarez, E.; Guillén, L.; Lambert, K.; Baidez, A.; García-Quesada, M.; Andreo, M.; Alom, J.; Masiá, M.; Gutiérrez, F. COVID-19-associated encephalitis successfully treated with combination therapy. Clin. Infect. Pract. 2020, 100053. [CrossRef]

84. Goodloe, T.B. 3rd, Walter LA. COVID-19 Presenting as Encephalopathy in the Emergency Department: A Case Report. Clin. Pract. Cases Emerg. Med. 2021, 5, 26-29. [CrossRef] 
85. Hayashi, M.; Sahashi, Y.; Baba, Y.; Okura, H.; Shimohata, T. COVID-19-associated mild encephalitis/encephalopathy with a reversible splenial lesion. J. Neurol. Sci. 2020,415, 116941. [CrossRef]

86. Langley, L.; Zeicu, C.; Whitton, L.; Pauls, M. Acute disseminated encephalomyelitis (ADEM) associated with COVID-19. BMJ Case Rep. 2020, 13, e239597. [CrossRef]

87. Muccioli, L.; Pensato, U.; Bernabè, G.; Ferri, L.; Tappatà, M.; Volpi, L.; Cani, I.; Henry, O.J.; Ceccaroni, F.; Cevoli, S.; et al. Intravenous immunoglobulin therapy in COVID-19-related encephalopathy. J. Neurol. 2020, 1-5. [CrossRef]

88. Pensato, U.; Muccioli, L.; Pasini, E.; Tappatà, M.; Ferri, L.; Volpi, L.; Licchetta, L.; Battaglia, S.; Rossini, G.; Bon, I.; et al. Encephalopathy in COVID-19 Presenting with Acute Aphasia Mimicking Stroke. Front. Neurol. 2020, 11, 587226. [CrossRef] [PubMed]

89. Sattar, S.B.A.; Haider, M.A.; Zia, Z.; Niazi, M.; Iqbal, Q.Z. Clinical, Radiological, and Molecular Findings of Acute Encephalitis in a COVID-19 Patient: A Rare Case Report. Cureus 2020, 12, e10650. [CrossRef] [PubMed]

90. Vandervorst, F.; Guldolf, K.; Peeters, I.; Vanderhasselt, T.; Michiels, K.; Berends, K.J.; Van Laethem, J.; Pipeleers, L.; Vincken, S.; Seynaeve, L.; et al. Encephalitis associated with the SARS-CoV-2 virus: A case report. Interdiscip. Neurosurg. 2020, $22,100821$. [CrossRef] [PubMed]

91. Virhammar, J.; Kumlien, E.; Fällmar, D.; Frithiof, R.; Jackmann, S.; Sköld, M.K.; Kadir, M.; Frick, J.; Lindeberg, J.; Olivero-Reinius, H.; et al. Acute necrotizing encephalopathy with SARS-CoV-2 RNA confirmed in cerebrospinal fluid. Neurology 2020, 95, 445-449. [CrossRef] [PubMed]

92. Pizzanelli, C.; Milano, C.; Canovetti, S.; Tagliaferri, E.; Turco, F.; Verdenelli, S.; Nesti, L.; Franchi, M.; Bonanni, E.; Menichetti, F.; et al. Autoimmune limbic encephalitis related to SARS-CoV-2 infection: Case-report and review of the literature. Brain Behav. Immun. Health 2021, 12, 100210. [CrossRef]

93. Grimaldi, S.; Lagarde, S.; Harlé, J.R.; Boucraut, J.; Guedj, E. Autoimmune Encephalitis Concomitant with SARS-CoV-2 Infection: Insight from ${ }^{18}$ F-FDG PET Imaging and Neuronal Autoantibodies. J. Nucl. Med. 2020, 61, 1726-1729. [CrossRef]

94. Khodamoradi, Z.; Hosseini, S.A.; Gholampoor Saadi, M.H.; Mehrabi, Z.; Sasani, M.R.; Yaghoubi, S. COVID-19 meningitis without pulmonary involvement with positive cerebrospinal fluid PCR. Eur. J. Neurol. 2020, 27, 2668-2669. [CrossRef] [PubMed]

95. Espíndola, O.M.; Siqueira, M.; Soares, C.N.; Lima, M.A.S.D.; Leite, A.C.C.B.; Araujo, A.Q.C.; Brandão, C.O.; Silva, M.T.T. Patients with COVID-19 and neurological manifestations show undetectable SARS-CoV-2 RNA levels in the cerebrospinal fluid. Int. J. Infect. Dis. 2020, 96, 567-569. [CrossRef] [PubMed]

96. Varatharaj, A.; Thomas, N.; Ellul, M.A.; Davies, N.W.S.; Pollak, T.A.; Tenorio, E.L.; Sultan, M.; Easton, A.; Breen, G.; Zandi, M.; et al. Neurological and neuropsychiatric complications of COVID-19 in 153 patients: A UK-wide surveillance study. Lancet Psychiatry 2020, 7, 875-882. [CrossRef]

97. Islam, M.R.; Rahman, T.; Ahmed, S.; Khan, M.S.; Azad, M.R.; Alam, D.; Habib, R. Neurological presentation of COVID-19: Experience from a tertiary care hospital of Bangladesh. BIRDEM Med. J. 2020, 10, 33-40. [CrossRef]

98. Khedr, E.M.; Abo-Elfetoh, N.; Deaf, E.; Hassan, H.M.; Amin, M.T.; Soliman, R.K.; Atta, A.A.; Zarzour, A.A.; Zain, M.; MohamedHussein, A.; et al. Surveillance Study of Acute Neurological Manifestations among 439 Egyptian Patients with COVID-19 in Assiut and Aswan University Hospitals. Neuroepidemiology 2021, 55, 109-118. [CrossRef]

99. Andrea, M.; Christian, M.; Lorenzo, M.; Francesco, D.; Walter, A.; Marco, M.; Andreina, B.; Maria, G.; Paolo, G.; Daniela, D.; et al. Unusual Presentation of COVID-19: Encephalitis and Syndrome of Inappropriate Anti-Diuretic Hormone Secretion. Int. J. Clin. Med. 2020, 11, 559-564. [CrossRef]

100. Tristán-Samaniego, D.P.; Chiquete, E.; Treviño-Frenk, I.; Rubalcava-Ortega, J.; Higuera-Calleja, J.A.; Romero-Sánchez, G.; Espinoza-Alvarado, L.; Barrera-Vargas, A.; Flores-Silva, F.; González-Duarte, A.; et al. COVID-19-related diffuse posthypoxic leukoencephalopathy and microbleeds masquerades as acute necrotizing encephalopathy. Int. J. Neurosci 2020, 1-6. [CrossRef]

101. Rajdev, K.; Victor, N.; Buckholtz, E.S.; Hariharan, P.; Saeed, M.A.; Hershberger, D.M.; Bista, S.A. Case of Guillain-Barré Syndrome Associated with COVID-19. J. Investig. Med. High Impact. Case Rep. 2020, 8, 2324709620961198. [CrossRef]

102. Chan, J.L.; Ebadi, H.; Sarna, J.R. Guillain-Barré Syndrome with Facial Diplegia Related to SARS-CoV-2 Infection. Can. J. Neurol. Sci. 2020, 47, 852-854. [CrossRef]

103. Juliao Caamaño, D.S.; Alonso Beato, R. Facial diplegia, a possible atypical variant of Guillain-Barré Syndrome as a rare neurological complication of SARS-CoV-2. J. Clin. Neurosci. 2020, 77, 230-232. [CrossRef]

104. Colonna, S.; Sciumé, L.; Giarda, F.; Innocenti, A.; Beretta, G.; Dalla Costa, D. Case Report: Postacute Rehabilitation of Guillain-Barré Syndrome and Cerebral Vasculitis-Like Pattern Accompanied by SARS-CoV-2 Infection. Front. Neurol. 2021, 11, 602554. [CrossRef]

105. Fadakar, N.; Ghaemmaghami, S.; Masoompour, S.M.; Shirazi Yeganeh, B.; Akbari, A.; Hooshmandi, S.; Ostovan, V.R. A First Case of Acute Cerebellitis Associated with Coronavirus Disease (COVID-19): A Case Report and Literature Review. Cerebellum 2020, 19, 911-914. [CrossRef]

106. Taylor, L.D.; Ameen, O.S.; Zaharie, S.D. Complete Clinicopathological Case Report of a Young Patient Dying of COVID-19-Related Stroke. Am. J. Forensic. Med. Pathol. 2021. [CrossRef] [PubMed]

107. Elhassan, M.; Saidahmed, O.; Adebayo, A.; Archibald, N. Persistent Cortical Blindness Following Posterior Reversible Encephalopathy Syndrome (PRES) as a Complication of COVID-19 Pneumonia. Cureus 2021, 13, e12794. [CrossRef]

108. Princiotta Cariddi, L.; Tabaee Damavandi, P.; Carimati, F.; Banfi, P.; Clemenzi, A.; Marelli, M.; Giorgianni, A.; Vinacci, G.; Mauri, M.; Versino, M. Reversible Encephalopathy Syndrome (PRES) in a COVID-19 patient. J. Neurol. 2020, 267, 3157-3160. [CrossRef] 
109. Cavalcanti, D.D.; Raz, E.; Shapiro, M.; Dehkharghani, S.; Yaghi, S.; Lillemoe, K.; Nossek, E.; Torres, J.; Jain, R.; Riina, H.A.; et al. Cerebral Venous Thrombosis Associated with COVID-19. AJNR. Am. J. Neuroradiol. 2020, 41, 1370-1376. [CrossRef] [PubMed]

110. Fu, B.; Chen, Y.; Li, P. Novel coronavirus disease with secondary ischemic stroke: Two case reports. BMC Neurol. 2021, 21, 4. [CrossRef]

111. Kadono, Y.; Nakamura, Y.; Ogawa, Y.; Yamamoto, S.; Kajikawa, R.; Nakajima, Y.; Matsumoto, M.; Kishima, H. A case of COVID-19 infection presenting with a seizure following severe brain edema. Seizure 2020, 80, 53-55. [CrossRef] [PubMed]

112. Klein, D.E.; Libman, R.; Kirsch, C.; Arora, R. Cerebral venous thrombosis: A typical presentation of COVID-19 in the young. J. Stroke Cerebrovasc. Dis. 2020, 29, 104989. [CrossRef] [PubMed]

113. Oxley, T.J.; Mocco, J.; Majidi, S.; Kellner, C.P.; Shoirah, H.; Singh, I.P.; De Leacy, R.A.; Shigematsu, T.; Ladner, T.R.; Yaeger, K.A.; et al. Large-Vessel Stroke as a Presenting Feature of Covid-19 in the Young. N. Engl. J. Med. 2020, 382, e60. [CrossRef]

114. Prasad, A.; Kataria, S.; Srivastava, S.; Lakhani, D.A.; Sriwastava, S. Multiple embolic stroke on magnetic resonance imaging of the brain in a COVID-19 case with persistent encephalopathy. Clin. Imaging 2021, 69, 285-288. [CrossRef] [PubMed]

115. Rudilosso, S.; Esteller, D.; Urra, X.; Chamorro, Á. Thalamic perforating artery stroke on computed tomography perfusion in a patient with coronavirus disease 2019. J. Stroke Cerebrovasc. Dis. 2020, 29, 104974. [CrossRef]

116. Saitta, L.; Molin, A.; Villani, F.; Insorsi, A.; Roccatagliata, L.; Inglese, M.; Bassetti, M.; Pelosi, P.; Castellan, L.; Gerevini, S.; et al. Brain microvascular occlusive disorder in COVID-19: A case report. Neurol. Sci. 2020, 41, 3401-3404. [CrossRef] [PubMed]

117. Shawkat, A.; Merrell, E.T.; Fadel, G.A.; Amzuta, I.; Amin, H.; Shah, A.J.; Habeb, H.; Aiash, H. Multiple Thrombotic Events in a 67-Year-Old Man 2 Weeks After Testing Positive for SARS-CoV-2: A Case Report. Am. J. Case. Rep. 2020, 21, e925786. [CrossRef] [PubMed]

118. Sugiyama, Y.; Tsuchiya, T.; Tanaka, R.; Ouchi, A.; Motoyama, A.; Takamoto, T.; Hara, N.; Yanagawa, Y. Cerebral venous thrombosis in COVID-19-associated coagulopathy: A case report. J. Clin. Neurosci. 2020, 79, 30-32. [CrossRef] [PubMed]

119. Tunç, A.; Ünlübaş, Y.; Alemdar, M.; Akyüz, E. Coexistence of COVID-19 and acute ischemic stroke report of four cases. J. Clin. Neurosci. 2020, 77, 227-229. [CrossRef]

120. Ahmad, H.; Shubair, S.M.; Kruer, J.; Hatoum, C.A. Acute Lower-Extremity Ischemia in a Patient with COVID-19. Am. J. Case Rep. 2021, 22, e928471. [CrossRef]

121. Yeganegi, M.; Fattahi, P. Management and Prevention of Cerebrovascular Accidents in SARS-CoV-2-Positive Patients Recovering from COVID-19: A Case Report and Review of Literature. SN Compr. Clin. Med. 2021, 1-12. [CrossRef]

122. Flores, G.; Kumar, J.I.; Pressman, E.; Sack, J.; Alikhani, P. Spontaneous Brainstem Hemorrhagic Stroke in the Setting of Novel Coronavirus Disease 2019-A Case Report. Cureus 2020, 12, e10809. [CrossRef]

123. Keller, E.; Brandi, G.; Winklhofer, S.; Imbach, L.L.; Kirschenbaum, D.; Frontzek, K.; Steiger, P.X.; Dietlerx, S.; Haeberlin, M.; Willms, J.; et al. Large and Small Cerebral Vessel Involvement in Severe COVID-19: Detailed Clinical Workup of a Case Series. Stroke 2020, 51, 3719-3722. [CrossRef] [PubMed]

124. Nawabi, J.; Morotti, A.; Wildgruber, M.; Boulouis, G.; Kraehling, H.; Schlunk, F.; Can, E.; Kniep, H.; Thomalla, G.; Psychogios, M.; et al. Clinical and Imaging Characteristics in Patients with SARS-CoV-2 Infection and Acute Intracranial Hemorrhage. J. Clin. Med. 2020, 9, 2543. [CrossRef] [PubMed]

125. Abouhashem, S.; Eldawoody, H.; Taha, M.M. Cerebral venous sinus thrombosis in patients with COVID-19 infection. Interdiscip. Neurosurg. 2021, 24, 101091. [CrossRef] [PubMed]

126. Thibodeau, R.; Jafroodifar, A.; Quraeshi, S.; Lisi, M. SARS-CoV-2 infection leading to ischemic and hemorrhagic brain lesions and acute respiratory distress syndrome. Radiol. Case. Rep. 2021, 16, 753-759. [CrossRef] [PubMed]

127. Caronna, E.; Ballvé, A.; Llauradó, A.; Gallardo, V.J.; Ariton, D.M.; Lallana, S.; López Maza, S.; Gadea, M.O.; Quibus, L.; Restrepo, J.L.; et al. Headache: A striking prodromal and persistent symptom, predictive of COVID-19 clinical evolution. Cephalalgia 2020, 13, 1410-1421. [CrossRef]

128. Sia, J. Dizziness can be an early sole clinical manifestation for COVID-19 infection: A case report. J. Am. Coll. Emerg. Physicians Open 2020, 1, 1354-1356. [CrossRef] [PubMed]

129. Spinato, G.; Fabbris, C.; Polesel, J.; Cazzador, D.; Borsetto, D.; Hopkins, C.; Boscolo-Rizzo, P. Alterations in Smell or Taste in Mildly Symptomatic Outpatients With SARS-CoV-2 Infection. JAMA 2020, 323, 2089-2090. [CrossRef]

130. Kandemirli, S.G.; Altundag, A.; Yildirim, D.; Tekcan Sanli, D.E.; Saatci, O. Olfactory Bulb MRI and Paranasal Sinus CT Findings in Persistent COVID-19 Anosmia. Acad. Radiol. 2021, 28, 28-35. [CrossRef]

131. Vargas-Gandica, J.; Winter, D.; Schnippe, R.; Rodriguez-Morales, A.G.; Mondragon, J.; Escalera-Antezana, J.P.; Trelles-Thorne, M.D.P.; Bonilla-Aldana, D.K.; Rodriguez-Morales, A.J.; Paniz-Mondolfi, A. Ageusia and anosmia, a common sign of COVID-19? A case series from four countries. J. Neurovirol. 2020, 26, 785-789. [CrossRef]

132. Lechien, J.R.; Chiesa-Estomba, C.M.; De Siati, D.R.; Horoi, M.; Le Bon, S.D.; Rodriguez, A.; Dequanter, D.; Blecic, S.; El Afia, F.; Distinguin, L.; et al. Olfactory and gustatory dysfunctions as a clinical presentation of mild-to-moderate forms of the coronavirus disease (COVID-19): A multicenter European study. Eur. Arch. Otorhinolaryngol. 2020, 277, 2251-2261. [CrossRef]

133. Ebrahimpour, S.; Mohseni Afshar, Z.; Mohseni, S.; Masrour-Roudsari, J.; Oladzade, S.; Bayani, M.; Babazadeh, A. Neurologic manifestations in patients with COVID-19: A case report. Caspian J. Intern. Med. 2020, 11, 557-560. [CrossRef] [PubMed]

134. Hampshire, A.; Trender, W.; Chamberlain, S.R.; Jolly, A.; Grant, J.E.; Patrick, F.; Mazibuko, N. Steve CR Williams, Joseph M Barnby, Peter Hellyer, Mitul A Mehta. Cognitive deficits in people who have recovered from COVID-19 relative to controls: An $\mathrm{N}=84,285$ online study. medRxiv 2020. [CrossRef] 
135. Guilmot, A.; Maldonado Slootjes, S.; Sellimi, A.; Bronchain, M.; Hanseeuw, B.; Belkhir, L.; Yombi, J.C.; De Greef, J.; Pothen, L.; Yildiz, H.; et al. Immune-mediated neurological syndromes in SARS-CoV-2-infected patients. J. Neurol. 2020, 30, 1-7. [CrossRef]

136. Alkeridy, W.A.; Almaghlouth, I.; Alrashed, R.; Alayed, K.; Binkhamis, K.; Alsharidi, A.; Liu-Ambrose, T.A. Unique Presentation of Delirium in a Patient with Otherwise Asymptomatic COVID-19. J. Am. Geriatr. Soc. 2020, 68, 1382-1384. [CrossRef] [PubMed]

137. Izquierdo Zarazaga, A.; Delgado Parada, E.; Santamaría Núnez, M.; López Cruz, A.; Pardo Corral, M.; Ximénez-Carrillo, A. Hipótesis neuroinvasiva en un caso de delirium atípico en paciente con neumonía por COVID-19. Psiq. Biol. 2020. [CrossRef]

138. Lu, S.; Wei, N.; Jiang, J.; Wu, L.; Sheng, J.; Zhou, J.; Fang, Q.; Chen, Y.; Zheng, S.; Chen, F.; et al. First report of manic-like symptoms in a COVID-19 patient with no previous history of a psychiatric disorder. J. Affect. Disord. 2020, 277, 337-340. [CrossRef] [PubMed]

139. Méndez-Guerrero, A.; Laespada-García, M.I.; Gómez-Grande, A.; Ruiz-Ortiz, M.; Blanco-Palmero, V.A.; Azcarate-Diaz, F.J.; Rábano-Suárez, P.; Álvarez-Torres, E.; de Fuenmayor-Fernández de la Hoz, C.P.; Vega Pérez, D.; et al. Acute hypokinetic-rigid syndrome following SARS-CoV-2 infection. Neurology 2020, 95, e2109-e2118. [CrossRef]

140. Panico, F.; Arini, A.; Cantone, P.; Crisci, C.; Trojano, L. Balint-Holmes syndrome due to stroke following SARS-CoV-2 infection: A single-case report. Neurol. Sci. 2020, 41, 3487-3489. [CrossRef]

141. Elkhaled, W.; Ben Abid, F.; Akhtar, N.; Abukamar, M.R.; Ibrahim, W.H. A 23-Year-Old Man with SARS-CoV-2 Infection Who Presented with Auditory Hallucinations and Imaging Findings of Cytotoxic Lesions of the Corpus Callosum (CLOCC). Am. J. Case. Rep. 2020, 21, e928798. [CrossRef]

142. Lin, J.; Lawson, E.C.; Verma, S.; Peterson, R.B.; Sidhu, R. Cytotoxic Lesion of the Corpus Callosum in an Adolescent with Multisystem Inflammatory Syndrome and SARS-CoV-2 Infection. AJNR Am. J. Neuroradiol. 2020, 41, 2017-2019. [CrossRef] [PubMed]

143. Moreau, A.; Ego, A.; Vandergheynst, F.; Taccone, F.S.; Sadeghi, N.; Montesinos, I.; Gaspard, N.; Gorham, J. Cytotoxic lesions of the corpus callosum (CLOCCs) associated with SARS-CoV-2 infection. J. Neurol. 2020, 1-3. [CrossRef]

144. Zanin, L.; Saraceno, G.; Panciani, P.P.; Renisi, G.; Signorini, L.; Migliorati, K.; Fontanella, M.M. SARS-CoV-2 can induce brain and spine demyelinating lesions. Acta Neurochir. 2020, 162, 1491-1494. [CrossRef] [PubMed]

145. Chu, C.M.; Cheng, V.C.; Hung, I.F.; Wong, M.M.; Chan, K.H.; Chan, K.S.; Kao, R.Y.; Poon, L.L.; Wong, C.L.; Guan, Y.; et al. Role of lopinavir/ritonavir in the treatment of SARS: Initial virological and clinical findings. Thorax 2004, 59, $252-256$. [CrossRef] [PubMed]

146. Thorlund, K.; Dron, L.; Park, J.; Hsu, G.; Forrest, J.I.; Mills, E. A real-time dashboard of clinical trials for COVID-19. Lancet. Digi. Health 2020, 2, e286-e287. [CrossRef]

147. Savarino, A.; Boelaert, J.R.; Cassone, A.; Majori, G.; Cauda, R. Effects of chloroquine on viral infections: An old drug against today's diseases? Lancet Infect. Dis. 2003, 3, 722-727. [CrossRef]

148. Xu, X.; Han, M.; Li, T.; Sun, W.; Wang, D.; Fu, B.; Zhou, Y.; Zheng, X.; Yang, Y.; Li, X.; et al. Effective treatment of severe COVID-19 patients with tocilizumab. Proc. Natl. Acad. Sci. USA 2020, 117, 10970-10975. [CrossRef] [PubMed]

149. Shang, C.; Zhuang, X.; Zhang, H.; Li, Y.; Zhu, Y.; Lu, J.; Ge, C.; Cong, J.; Li, T.; Tian, M.; et al. Inhibitors of endosomal acidification suppress SARS-CoV-2 replication and relieve viral pneumonia in hACE2 transgenic mice. Virol. J. 2021, 18, 46. [CrossRef]

150. Diaz-Arocutipa, C.; Brañez-Condorena, A.; Hernandez, A.V. QTc prolongation in COVID-19 patients treated with hydroxychloroquine, chloroquine, azithromycin, or lopinavir/ritonavir: A systematic review and meta-analysis. Pharmacoepidemiol. Drug. Saf. 2021. [CrossRef]

151. Richardson, P.; Griffin, I.; Tucker, C.; Smith, D.; Oechsle, O.; Phelan, A.; Rawling, M.; Savory, E.; Stebbing, J. Baricitinib as potential treatment for 2019-nCoV acute respiratory disease. Lancet 2020, 395, e30-e31. [CrossRef]

152. Jaggers, G.K.; Watkins, B.A.; Rodriguez, R.L. COVID-19: Repositioning nutrition research for the next pandemic. Nutr. Res. 2020, 81, 1-6. [CrossRef]

153. Klok, F.A.; Kruip, M.J.H.A.; van der Meer, N.J.M.; Arbous, M.S.; Gommers, D.A.M.P.J.; Kant., K.M.; Kaptein, F.H.J.; van Paassen, J.; Stals, M.A.M.; Huisman, M.V.; et al. Incidence of thrombotic complications in critically ill ICU patients with COVID-19. Thromb. Res. 2020, 191, 145-147. [CrossRef] [PubMed]

154. Barrett, C.D.; Moore, H.B.; Yaffe, M.B.; Moore, E.E. ISTH interim guidance on recognition and management of coagulopathy in COVID-19: A comment. J. Thromb. Haemost. 2020, 18, 2060-2063. [CrossRef] [PubMed]

155. Moore, H.B.; Barrett, C.D.; Moore, E.E.; McIntyre, R.C.; Moore, P.K.; Talmor, D.S.; Moore, F.A.; Yaffe, M.B. Is there a role for tissue plasminogen activator as a novel treatment for refractory COVID-19 associated acute respiratory distress syndrome? J. Trauma Acute Care Surg. 2020, 88, 713-714. [CrossRef] [PubMed]

156. Ong, W.Y.; Go, M.L.; Wang, D.Y.; Cheah, I.K.; Halliwell, B. Effects of Antimalarial Drugs on Neuroinflammation-Potential Use for Treatment of COVID-19-Related Neurologic Complications. Mol. Neurobiol. 2021, 58, 106-117. [CrossRef] [PubMed]

157. Jaworowski, S.; Weiser, M.; Gropp, C.; Malka, M. Three Cases of COVID-19-related First Onset Brief Reactive Psychosis. Isr. Med. Assoc. J. 2020, 22, 612. [PubMed]

158. Anmella, G.; Arbelo, N.; Fico, G.; Murru, A.; Llach, C.D.; Madero, S.; Gomes-da-Costa, S.; Imaz, M.L.; López-Pelayo, H.; Vieta, E.; et al. COVID-19 inpatients with psychiatric disorders: Real-world clinical recommendations from an expert team in consultation-liaison psychiatry. J. Affect. Disord. 2020, 274, 1062-1067. [CrossRef]

159. Zeng, L.; Zhang, H.; He, Y.; Lai, B.; Huang, Z.; Lin, L.; Zhong, Z.; Guo, X. A severe COVID-19 case with schizophrenia as well as other chronic diseases. Braz. J. Med. Biol. Res. 2021, 54, e10426. [CrossRef] [PubMed] 
160. Castillo, R.R.; Quizon, G.R.A.; Juco, M.J.M.; Roman, A.D.E.; de Leon, D.G.; Punzalan, F.E.R.; Guingon, R.B.L.; Morales, D.D.; Tan, D.-X.; Reiter, R.J. Melatonin as adjuvant treatment for coronavirus disease 2019 pneumonia patients requiring hospitalization (MAC-19 PRO): A case series. Melatonin Res. 2020, 297-310. [CrossRef]

161. Sher, Y.; Rabkin, B.; Maldonado, J.R.; Mohabir, P. COVID-19-Associated Hyperactive Intensive Care Unit Delirium with Proposed Pathophysiology and Treatment: A Case Report. Psychosomatics 2020, 61, 544-550. [CrossRef]

162. Baller, E.B.; Hogan, C.S.; Fusunyan, M.A.; Ivkovic, A.; Luccarelli, J.W.; Madva, E.; Nisavic, M.; Praschan, N.; Quijije, N.V.; Beach, S.R.; et al. Neurocovid: Pharmacological Recommendations for Delirium Associated With COVID-19. Psychosomatics 2020, 61, 585-596. [CrossRef]

163. Van Vuren, E.J.; Steyn, S.F.; Brink, C.B.; Möller, M.; Viljoen, F.P.; Harvey, B.H. The neuropsychiatric manifestations of COVID-19: Interactions with psychiatric illness and pharmacological treatment. Biomed. Pharmacother. 2021, 135, 111200. [CrossRef] [PubMed]

164. El-Zein, R.S.; Cardinali, S.; Murphy, C.; Keeling, T. COVID-19-associated meningoencephalitis treated with intravenous immunoglobulin. BMJ Case Rep. 2020, 13, e237364. [CrossRef] [PubMed]

165. Halliwell, B.; Gutteridge, J. Free Radical in Biology and Medicine, 5th ed.; Oxford University Press: New York, NY, USA, 2015. [CrossRef]

166. Kim, H.J.; Kim, C.H.; Ryu, J.H.; Kim, M.J.; Park, C.Y.; Lee, J.M.; Holtzman, M.J.; Yoon, J.H. Reactive oxygen species induce antiviral innate immune response through IFN- $\lambda$ regulation in human nasal epithelial cells. Am. J. Respir. Cell. Mol. Biol. 2013, 49, 855-865. [CrossRef]

167. Khomich, O.A.; Kochetkov, S.N.; Bartosch, B.; Ivanov, A.V. Redox Biology of Respiratory Viral Infections. Viruses 2018, 10, 392. [CrossRef]

168. Griffith, B.; Pendyala, S.; Hecker, L.; Lee, P.J.; Natarajan, V.; Thannickal, V.J. NOX enzymes and pulmonary disease. Antioxid. Redox. Signal. 2009, 11, 2505-2516. [CrossRef] [PubMed]

169. Akki, R.; Fath, N.; Mohti, H. COVID-19: Oxidative Preconditioning as a Potential Therapeutic Approach. ACS Chem. Neurosci. 2020, 11, 3732-3740. [CrossRef]

170. Komaravelli, N.; Casola, A. Respiratory Viral Infections and Subversion of Cellular Antioxidant Defenses. J. Pharmacogenom. Pharmacoproteom. 2014, 5, 1000141. [CrossRef]

171. Laforge, M.; Elbim, C.; Frère, C.; Hémadi, M.; Massaad, C.; Nuss, P.; Benoliel, J.J.; Becker, C. Tissue damage from neutrophilinduced oxidative stress in COVID-19. Nat. Rev. Immunol. 2020, 20, 515-516. [CrossRef]

172. Liu, Y.; Du, X.; Chen, J.; Jin, Y.; Peng, L.; Wang, H.; Luo, M.; Chen, L.; Zhao, Y. Neutrophil-to-lymphocyte ratio as an independent risk factor for mortality in hospitalized patients with COVID-19. J. Infect. 2020, 81, e6-e12. [CrossRef] [PubMed]

173. Qin, C.; Zhou, L.; Hu, Z.; Zhang, S.; Yang, S.; Tao, Y.; Xie, C.; Ma, K.; Shang, K.; Wang, W.; et al. Dysregulation of Immune Response in Patients with Coronavirus 2019 (COVID-19) in Wuhan, China. Clin. Infect. Dis. 2020, 71, 762-768. [CrossRef]

174. Wang, D.; Hu, B.; Hu, C.; Zhu, F.; Liu, X.; Zhang, J.; Wang, B.; Xiang, H.; Cheng, Z.; Xiong, Y.; et al. Clinical Characteristics of 138 Hospitalized Patients With 2019 Novel Coronavirus-Infected Pneumonia in Wuhan, China. JAMA 2020, 323, 1061-1069. [CrossRef]

175. Zhang, B.; Zhou, X.; Zhu, C.; Song, Y.; Feng, F.; Qiu, Y.; Feng, J.; Jia, Q.; Song, Q.; Zhu, B.; et al. Immune Phenotyping Based on the Neutrophil-to-Lymphocyte Ratio and IgG Level Predicts Disease Severity and Outcome for Patients With COVID-19. Front Mol. Biosci. 2020, 7, 157. [CrossRef] [PubMed]

176. Schönrich, G.; Raftery, M.J.; Samstag, Y. Devilishly radical NETwork in COVID-19: Oxidative stress, neutrophil extracellular traps (NETs), and T cell suppression. Adv. Biol. Regul. 2020, 77, 100741. [CrossRef] [PubMed]

177. Li, S.W.; Wang, C.Y.; Jou, Y.J.; Yang, T.C.; Huang, S.H.; Wan, L.; Lin, Y.J.; Lin, C.W. SARS coronavirus papain-like protease induces Egr-1-dependent up-regulation of TGF- $\beta 1$ via ROS/p38 MAPK/STAT3 pathway. Sci. Rep. 2016, 6, 25754. [CrossRef] [PubMed]

178. Griendling, K.K.; Sorescu, D.; Lassègue, B.; Ushio-Fukai, M. Modulation of protein kinase activity and gene expression by reactive oxygen species and their role in vascular physiology and pathophysiology. Arterioscler. Thromb. Vasc. Biol. 2000, 20, 2175-2183. [CrossRef] [PubMed]

179. Dikalov, S. Cross talk between mitochondria and NADPH oxidases. Free Radic. Biol. Med. 2011, 51, 1289-1301. [CrossRef]

180. Pignatelli, P.; Carnevale, R.; Cammisotto, V.; Lichtner, M.; Alessandri, F.; De Angelis, M.; Miele, M.C.; D’Ettorre, G.; Ruberto, F.; Venditti, M.; et al. Nox2 activation in Covid-19. Redox. Biol. 2020, 36, 101655. [CrossRef]

181. Wen, H.; Gwathmey, J.K.; Xie, L.H. Oxidative stress-mediated effects of angiotensin II in the cardiovascular system. World J. Hypertens. 2012, 2, 34-44. [CrossRef]

182. Wang, H.; Yang, P.; Liu, K.; Guo, F.; Zhang, Y.; Zhang, G.; Jiang, C. SARS coronavirus entry into host cells through a novel clathrinand caveolae-independent endocytic pathway. Cell Res. 2008, 8, 290-301. [CrossRef]

183. Beltrán-García, J.; Osca-Verdegal, R.; Pallardó, F.V.; Ferreres, J.; Rodríguez, M.; Mulet, S.; Sanchis-Gomar, F.; Carbonell, N.; García-Giménez, J.L. Oxidative Stress and Inflammation in COVID-19-Associated Sepsis: The Potential Role of Anti-Oxidant Therapy in Avoiding Disease Progression. Antioxidants 2020, 9, 936. [CrossRef] [PubMed]

184. Suhail, S.; Zajac, J.; Fossum, C.; Lowater, H.; McCracken, C.; Severson, N.; Laatsch, B.; Narkiewicz-Jodko, A.; Johnson, B.; Liebau, J.; et al. Role of Oxidative Stress on SARS-CoV (SARS) and SARS-CoV-2 (COVID-19) Infection: A Review. Protein J. 2020, 39, 644-656. [CrossRef]

185. Busse, L.W.; Chow, J.H.; McCurdy, M.T.; Khanna, A.K. COVID-19 and the RAAS-a potential role for angiotensin II? Crit. Care 2020, 24, 136. [CrossRef] 
186. Hati, S.; Bhattacharyya, S. Impact of Thiol-Disulfide Balance on the Binding of Covid-19 Spike Protein with AngiotensinConverting Enzyme 2 Receptor. CS Omega 2020, 5, 16292-16298. [CrossRef]

187. Rabelo, L.A.; Alenina, N.; Bader, M. ACE2-angiotensin-(1-7)-Mas axis and oxidative stress in cardiovascular disease. Hyper. Res. 2011, 34, 154-160. [CrossRef] [PubMed]

188. Blaser, H.; Dostert, C.; Mak, T.W.; Brenner, D. TNF and ROS Crosstalk in Inflammation. Trend. Cell. Biol. 2016, $26,249-261$. [CrossRef] [PubMed]

189. Pennathur, S.; Heinecke, J.W. Oxidative stress and endothelial dysfunction in vascular disease. Curr. Diab. Rep. 2007, 4, 257-264. [CrossRef]

190. Sandoval, R.; Lazcano, P.; Ferrari, F.; Pinto-Pardo, N.; González-Billault, C.; Utreras, E. TNF- $\alpha$ increases production of reactive oxygen species through Cdk5 activation in nociceptive neurons. Front. Physiol. 2018, 9, 65. [CrossRef]

191. Cavezzi, A.; Troiani, E.; Corrao, S. COVID-19: Hemoglobin, iron, and hypoxia beyond inflammation. A narrative review. Clin. Pract. 2020, 10, 1271. [CrossRef] [PubMed]

192. Saleh, J.; Peyssonnaux, C.; Singh, K.K.; Edeas, M. Mitochondria and microbiota dysfunction in COVID-19 pathogenesis. Mitochondrion 2020, 54, 1-7. [CrossRef]

193. Jo, E.K.; Kim, J.K.; Shin, D.M.; Sasakawa, C. Molecular mechanisms regulating NLRP3 inflammasome activation. Cell. Mol. Immunol. 2016, 13, 148-159. [CrossRef]

194. Naik, E.; Dixit, V.M. Mitochondrial reactive oxygen species drive proinflammatory cytokine production. J. Exp. Med. 2011, 208, 417-420. [CrossRef] [PubMed]

195. Zhang, Z.; Wang, L.; Peng, L.; Chen, L.; Qin, Y.; Zhao, D.; Tan, S.; Yin, L.; Xu, J.; Zhou, C.; et al. Clinical and biochemical indexes from 2019-nCoV infected patients linked to viral loads and lung injury. Sci. China Life Sci. 2020, 63, 364-374. [CrossRef]

196. Zhou, F.; Yu, T.; Du, R.; Fan, G.; Liu, Y.; Liu, Z.; Xiang, J.; Wang, Y.; Song, B.; Gu, X.; et al. Clinical course and risk factors for mortality of adult inpatients with COVID-19 in Wuhan, China: A retrospective cohort study. Lancet 2020, 395, 1054-1062. [CrossRef]

197. Abdennour, L.; Zeghal, C.; Dème, M.; Puybasset, L. Interaction cerveau-poumon [Interaction brain-lungs]. Ann. Fr. Anesth. Reanim. 2012, 31, e101-7. [CrossRef]

198. Olagnier, D.P. Identification of SARS-CoV2-mediated suppression of NRF2 signaling reveals a potent antiviral and antiinflammatory activity of 4-octyl-itaconate and dimethyl fumarate. Nat. Commun. 2020, 11, 5419. [CrossRef]

199. Cuadrado, A.; Pajares, M.; Benito, C.; Jiménez-Villegas, J.; Escoll, M.; Fernández-Ginés, R.; Garcia Yagüe, A.J.; Lastra, D.; Manda, G.; Rojo, A.I.; et al. Can Activation of NRF2 Be a Strategy against COVID-19? Trends. Pharmacol. Sci. 2020, 41, 598-610. [CrossRef]

200. Cuadrado, A. Therapeutic targeting of the NRF2 and KEAP1 partnership in chronic diseases. Nat. Rev. Drug Discov. 2019, 18, 295-317. [CrossRef]

201. Polonikov, A. Endogenous Deficiency of Glutathione as the Most Likely Cause of Serious Manifestations and Death in COVID-19 Patients. ACS Infect. Dis. 2020, 6, 1558-1562. [CrossRef]

202. Abraham, E.C.; Taylor, J.F.; Lang, C.A. Influence of mouse age and erythrocyte age on glutathione metabolism. Biochem J. 1978, 174, 819-825. [CrossRef]

203. Abouhashem, A.S.; Singh, K.; Azzazy, H.; Sen, C.K. Is Low Alveolar Type II Cell SOD3 in the Lungs of Elderly Linked to the Observed Severity of COVID-19? Antioxid. Redox. Signal. 2020, 33, 59-65. [CrossRef]

204. Ling, C.Q. Traditional Chinese medicine is a resource for drug discovery against 2019 novel coronavirus (SARS-CoV-2). J. Integr. Med. 2020, 18, 87-88. [CrossRef] [PubMed]

205. Mondal, S.; Karmakar, A.; Mallick, T.; Begum, N.A. Exploring the efficacy of naturally occurring biflavone based antioxidants towards the inhibition of the SARS-CoV-2 spike glycoprotein mediated membrane fusion. Virology 2021, 556, 133-139. [CrossRef] [PubMed]

206. Chikhale, R.V.; Gurav, S.S.; Patil, R.B.; Sinha, S.K.; Prasad, S.K.; Shakya, A.; Shrivastava, S.K.; Gurav, N.S.; Prasad, R.S. Sars-cov-2 host entry and replication inhibitors from Indian ginseng: An in-silico approach. J. Biomol. Struct. Dyn. 2020, 1-12. [CrossRef]

207. El-Missiry, M.A.; Fekri, A.; Kesar, L.A.; Othman, A.I. Polyphenols are potential nutritional adjuvants for targeting COVID-19. Phytother. Res. 2020. [CrossRef]

208. Su, H.; Yao, S.; Zhao, W.; Li, M.; Liu, J.; Shang, W.; Xie, H.; Ke, C.; Gao, M.; Yu, K.; et al. Discovery of baicalin and baicalein as novel, natural product inhibitors of SARS-CoV-2 3CL protease in vitro. BioRxiv 2020. [CrossRef]

209. Da Silva Antonio, A.; Wiedemann, L.S.M.; Veiga-Junior, V.F. Natural products' role against COVID-19. RSC Advan. 2020, 10, 23379-23393. [CrossRef]

210. Bhardwaj, V.K.; Singh, R.; Sharma, J.; Rajendran, V.; Purohit, R.; Kumar, S. Identification of bioactive molecules from tea plant as SARS-CoV-2 main protease inhibitors. J. Biomol. Struct. Dyn. 2020, 1-10. [CrossRef]

211. Huynh, T.; Wang, H.; Luan, B. In Silico Exploration of the Molecular Mechanism of Clinically Oriented Drugs for Possibly Inhibiting SARS-CoV-2's Main Protease. J. Phys. Chem. Lett. 2020, 11, 4413-4420. [CrossRef]

212. Enmozhi, S.K.; Raja, K.; Sebastine, I.; Joseph, J. Andrographolide as a potential inhibitor of SARS-CoV-2 main protease: An in silico approach. J. Biomol. Struct. Dyn. 2020, 1-10. [CrossRef]

213. Gurung, A.B.; Ali, M.A.; Lee, J.; Farah, M.A.; Al-Anazi, K.M. Unravelling lead antiviral phytochemicals for the inhibition of SARS-CoV-2 Mpro enzyme through in silico approach. Life Sci. 2020, 255, 117831. [CrossRef] 
214. Caruso, F.; Singh, M.; Belli, S.; Berinato, M.; Rossi, M. Interrelated Mechanism by Which the Methide Quinone Celastrol, Obtained from the Roots of Tripterygium wilfordii, Inhibits Main Protease $3 C^{\text {pro }}$ of COVID-19 and Acts as Superoxide Radical Scavenger. Int. J. Mol. Sci. 2020, 21, 9266. [CrossRef]

215. Chidambaram, S.K.; Ali, D.; Alarifi, S.; Radhakrishnan, S.; Akbar, I. In silico molecular docking: Evaluation of coumarin based derivatives against SARS-CoV-2. J. Infect. Public Health 2020, 13, 1671-1677. [CrossRef]

216. Feitosa, E.L.; Júnior, F.; Nery Neto, J.; Matos, L.; Moura, M.; Rosales, T.O.; De Freitas, G. COVID-19: Rational discovery of the therapeutic potential of Melatonin as a SARS-CoV-2 main Protease Inhibitor. Int. J. Med. Sci. 2020, 17, 2133-2146. [CrossRef]

217. Liang, J.; Karagiannis, C.; Pitsillou, E.; Darmawan, K.K.; Ng, K.; Hung, A.; Karagiannis, T.C. Site mapping and small molecule blind docking reveal a possible target site on the SARS-CoV-2 main protease dimer interface. Comput. Biol. Chem. 2020, 89, 107372. [CrossRef]

218. Kodchakorn, K.; Poovorawan, Y.; Suwannakarn, K.; Kongtawelert, P. Molecular modelling investigation for drugs and nutraceuticals against protease of SARS-CoV-2. J. Mol. Graph. Model. 2020, 101, 107717. [CrossRef]

219. Pandey, A.K.; Verma, S. An in-silico evaluation of dietary components for structural inhibition of SARS-Cov-2 main protease. J. Biomol. Struct. Dyn. 2020, 1-7. [CrossRef] [PubMed]

220. Abian, O.; Ortega-Alarcon, D.; Jimenez-Alesanco, A.; Ceballos-Laita, L.; Vega, S.; Reyburn, H.T.; Rizzuti, B.; Velazquez-Campoy, A. Structural stability of SARS-CoV-2 3CLpro and identification of quercetin as an inhibitor by experimental screening. Int. J. Biol. Macromol. 2020, 164, 1693-1703. [CrossRef]

221. Matondo, A.; Kilembe, J.T.; Mwanangombo, D.T.; Nsimba, B.M.; Gbolo, B.Z.; Bongo, G.N.; Ngbolua, K.-t.-N.; Tshilanda, D.D.; Tshibangu, D.S.T.; Mudogo, V.; et al. Facing COVID-19 via anti-inammatory mechanism of action: Molecular docking and Pharmacokinetic studies of six anti-inammatory compounds derived from Passiora edulis. Res. Square 2020. [CrossRef]

222. Mosquera-Yuqui, F.; Lopez-Guerra, N.; Moncayo-Palacio, E.A. Targeting the 3CLpro and RdRp of SARS-CoV-2 with phytochemicals from medicinal plants of the Andean Region: Molecular docking and molecular dynamics simulations. J. Biomol. Struct. Dyn. 2020, 1, 1-14. [CrossRef]

223. Lung, J.; Lin, Y.S.; Yang, Y.H.; Chou, Y.L.; Shu, L.H.; Cheng, Y.C.; Liu, H.T.; Wu, C.Y. The potential chemical structure of anti-SARS-CoV-2 RNA-dependent RNA polymerase. J. Med. Virol. 2020, 92, 693-697. [CrossRef] [PubMed]

224. Kandeel, M.; Kitade, Y.; Almubarak, A. Repurposing FDA-approved phytomedicines, natural products, antivirals and cell protectives against SARS-CoV-2 (COVID-19) RNA-dependent RNA polymerase. PeerJ 2020, 8, e10480. [CrossRef]

225. Mhatre, S.; Naik, S.; Patravale, V. A molecular docking study of EGCG and theaflavin digallate with the druggable targets of SARS-CoV-2. Comput. Biol. Med. 2021, 129, 104137. [CrossRef] [PubMed]

226. Rahman, F.; Tabrez, S.; Ali, R.; Alqahtani, A.S.; Ahmed, M.Z.; Rub, A. Molecular docking analysis of rutin reveals possible inhibition of SARS-CoV-2 vital proteins. J. Tradit. Complement. Med. 2021, 11, 173-179. [CrossRef]

227. Utomo, R.Y.; Ikawati, M.; Meiyanto, E. Revealing the Potency of Citrus and Galangal Constituents to Halt SARS-CoV-2 Infection. Preprints 2020. [CrossRef]

228. Chikhale, R.V.; Sinha, S.K.; Patil, R.B.; Prasad, S.K.; Shakya, A.; Gurav, N.; Prasad, R.; Dhaswadikar, S.R.; Wanjari, M.; Gurav, S.S. In-silico investigation of phytochemicals from Asparagus racemosus as plausible antiviral agent in COVID-19. J. Biomol. Struct. Dyn. 2020, 1-15. [CrossRef]

229. Jayawardena, R.; Sooriyaarachchi, P.; Chourdakis, M.; Jeewandara, C.; Ranasinghe, P. Enhancing immunity in viral infections, with special emphasis on COVID-19: A review. Diabetes Metab. Syndr. 2020, 14, 367-382. [CrossRef]

230. Reddy, G.J.; Hema, K.; Dodoala, S.; Koganti, B. Unravelling high-affinity binding compounds towards transmembrane protease serine 2 enzyme in treating SARS-CoV-2 infection using molecular modelling and docking studies. Eur. J. Pharmacol. 2021, 890, 173688. [CrossRef]

231. Kumar, S.; Kashyap, P.; Chowdhury, S.; Kumar, S.; Panwar, A.; Kumar, A. Identification of phytochemicals as potential therapeutic agents that binds to Nsp15 protein target of coronavirus (SARS-CoV-2) that are capable of inhibiting virus replication. Phytomedicine 2020, 153317. [CrossRef] [PubMed]

232. Maiti, S.; Banerjee, A.; Nazmeen, A.; Kanwar, M.; Das, S. Active-site Molecular docking of Nigellidine with nucleocapsidNSP2-MPro of COVID-19 and to human IL1R-IL6R and strong antioxidant role of Nigella-sativa in experimental rats. J. Drug. Target. 2020, 2, 1-23. [CrossRef]

233. Rolta, R.; Yadav, R.; Salaria, D.; Trivedi, S.; Imran, M.; Sourirajan, A.; Baumler, D.J.; Dev, K. In silico screening of hundred phytocompounds of ten medicinal plants as potential inhibitors of nucleocapsid phosphoprotein of COVID-19: an approach to prevent virus assembly. J. Biomol. Struct. Dyn. 2020, 1-8. [CrossRef]

234. Bhowmik, D.; Nandi, R.; Jagadeesan, R.; Kumar, N.; Prakash, A.; Kumar, D. Identification of potential inhibitors against SARS$\mathrm{CoV}-2$ by targeting proteins responsible for envelope formation and virion assembly using docking based virtual screening, and pharmacokinetics approaches. Infect. Genet. Evol. 2020, 84, 104451. [CrossRef]

235. Verma, V.A.; Saundane, A.R.; Meti, R.S.; Vennapu, D.R. Synthesis of novel indolo[3,2-c]isoquinoline derivatives bearing pyrimidine, piperazine rings and their biological evaluation and docking studies against COVID-19 virus main protease. J. Mol. Struct. 2021, 1229, 129829. [CrossRef]

236. Sepay, N.; Sekar, A.; Halder, U.C.; Alarifi, A.; Afzal, M. Anti-COVID-19 terpenoid from marine sources: A docking, admet and molecular dynamics study. J. Mol. Struct. 2021, 1228, 129433. [CrossRef] [PubMed] 
237. Alaşalvar, C.; Öztürk, N.; Gökce, H.; Güder, A.; Menteşe, E.; Bektaş, H. Synthesis, structural, spectral, antioxidant, bioactivity and molecular docking investigations of a novel triazole derivative. J. Biomol. Struct. Dyn. 2021, 1-14. [CrossRef] [PubMed]

238. Ranjbar, A.; Jamshidi, M.; Torabi, S. Molecular modelling of the antiviral action of Resveratrol derivatives against the activity of two novel SARS CoV-2 and 2019-nCoV receptors. Eur. Rev. Med. Pharmacol. Sci. 2020, 24, 7834-7844. [CrossRef] [PubMed]

239. Marinella, M.A. Indomethacin and resveratrol as potential treatment adjuncts for SARS-CoV-2/COVID-19. Int. J. Clin. Pract. 2020, 74, e13535. [CrossRef] [PubMed]

240. Zahedipour, F.; Hosseini, S.A.; Sathyapalan, T.; Majeed, M.; Jamialahmadi, T.; Al-Rasadi, K.; Banach, M.; Sahebkar, A. Potential effects of curcumin in the treatment of COVID-19 infection. Phytother. Res. 2020, 34, 2911-2920. [CrossRef]

241. Zhou, N.; Yang, X.; Huang, A.; Chen, Z. The potential mechanism of N-acetylcysteine in treating COVID-19. Curr. Pharm. Biotechnol. 2020. [CrossRef]

242. Paraiso, I.L.; Revel, J.S.; Stevens, J.F. Potential use of polyphenols in the battle against COVID-19. Curr. Opin. Food. Sci. 2020, 32, 149-155. [CrossRef]

243. Ahmad, S.; Abbasi, H.W.; Shahid, S.; Gul, S.; Abbasi, S.W. Molecular docking, simulation and MM-PBSA studies of Nigella sativa compounds: A computational quest to identify potential natural antiviral for COVID-19 treatment. J. Biomol. Struct. Dyn. 2020, 1-9. [CrossRef] [PubMed]

244. Ohta, S. Direct targets and subsequent pathways for molecular hydrogen to exert multiple functions: Focusing on interventions in radical reactions. Curr. Pharm. Des. 2021, 27, 595-609. [CrossRef]

245. Jorge-Aarón, R.M.; Rosa-Ester, M.P. N-acetylcysteine as a potential treatment for COVID-19. Future Microbiol. 2020, 15, 959-962. [CrossRef]

246. Banerjee, A.; Czinn, S.J.; Reiter, R.J.; Blanchard, T.G. Crosstalk between endoplasmic reticulum stress and anti-viral activities: A novel therapeutic target for COVID-19. Life Sci. 2020, 255, 117842. [CrossRef]

247. McCord, J.M.; Hybertson, B.M.; Cota-Gomez, A.; Geraci, K.P.; Gao, B. Nrf2 Activator PB125 ${ }^{\circledR}$ as a Potential Therapeutic Agent against COVID-19. Antioxidants 2020, 9, 518. [CrossRef]

248. Haggag, Y.A.; El-Ashmawy, N.E.; Okasha, K.M. Is hesperidin essential for prophylaxis and treatment of COVID-19 Infection? Med. Hypotheses 2020, 44, 109957. [CrossRef]

249. Takeda, Y.; Jamsransuren, D.; Matsuda, S.; Crea, R.; Ogawa, H. The SARS-CoV-2-Inactivating Activity of HydroxytyrosolRich Aqueous Olive Pulp Extract (HIDROX ${ }^{\circledR}$ ) and Its Use as a Virucidal Cream for Topical Application. Viruses 2021, 13, 232. [CrossRef] [PubMed]

250. Mattioli, A.V.; Toni, S.; Coppi, F.; Farinetti, A. Practical tips for prevention of cardiovascular disease in women after quarantine for COVID-19 disease. Acta Biomed. 2020, 91, e2020127. [CrossRef]

251. Becker, R.C. Covid-19 treatment update: Follow the scientific evidence. J. Thromb. Thrombolysis. 2020, 50, 43-53. [CrossRef]

252. Panyod, S.; Ho, C.T.; Sheen, L.Y. Dietary therapy and herbal medicine for COVID-19 prevention: A review and perspective. J. Tradit. Complement. Med. 2020, 10, 420-427. [CrossRef]

253. Zhang, D.; Guo, R.; Lei, L.; Liu, H.; Wang, Y.; Wang, Y.; Dai, T.; Zhang, T.; Lai, Y.; Wang, J.; et al. Frontline Science: COVID-19 infection induces readily detectable morphologic and inflammation-related phenotypic changes in peripheral blood monocytes. J. Leukoc. Biol. 2021, 109, 13-22. [CrossRef]

254. Messina, G.; Polito, R.; Monda, V.; Cipolloni, L.; Di Nunno, N.; Di Mizio, G.; Murabito, P.; Carotenuto, M.; Messina, A.; Pisanelli, D.; et al. Functional Role of Dietary Intervention to Improve the Outcome of COVID-19: A Hypothesis of Work. Int. J. Mol. Sci. 2020, 21, 3104. [CrossRef]

255. Grant, W.B.; Lahore, H.; McDonnell, S.L.; Baggerly, C.A.; French, C.B.; Aliano, J.L.; Bhattoa, H.P. Evidence that vitamin D supplementation could reduce risk of influenza and COVID-19 infections and deaths. Nutrients 2020, 12, 988. [CrossRef] [PubMed]

256. Annweiler, C.; Beaudenon, M.; Gautier, J.; Simon, R.; Dubée, V.; Gonsard, J.; Parot-Schinkel, E.; COVIT-TRIAL Study Group. COvid-19 and high-dose VITamin D supplementation TRIAL in high-risk older patients (COVIT-TRIAL): Study protocol for a randomized controlled trial. Trials 2020, 21, 1031. [CrossRef] [PubMed]

257. De Las Heras, N.; Martín Giménez, V.M.; Ferder, L.; Manucha, W.; Lahera, V. Implications of Oxidative Stress and Potential Role of Mitochondrial Dysfunction in COVID-19: Therapeutic Effects of Vitamin D. Antioxidants 2020, 9, 897. [CrossRef] [PubMed]

258. Gao, D.; Xu, M.; Wang, G.; Lv, J.; Ma, X.; Guo, Y.; Zhang, D.; Yang, H.; Jiang, W.; Deng, F.; et al. The efficiency and safety of high-dose vitamin C in patients with COVID-19: A retrospective cohort study. Aging 2021, 13, 7020-7034. [CrossRef] [PubMed]

259. Zh Zhao, B.; Ling, Y.; Li, J.; Peng, Y.; Huang, J.; Wang, Y.; Qu, H.; Gao, Y.; Li, Y.; Hu, B.; et al. Beneficial aspects of high dose intravenous vitamin C on patients with COVID-19 pneumonia in severe condition: A retrospective case series study. Ann. Palliat. Med. 2021, 10, 1599-1609. [CrossRef]

260. Oyagbemi, A.A.; Ajibade, T.O.; Aboua, Y.G.; Gbadamosi, I.T.; Adedapo, A.; Aro, A.O.; Adejumobi, O.A.; Thamahane-Katengua, E.; Omobowale, T.O.; Falayi, O.O.; et al. Potential health benefits of zinc supplementation for the management of COVID-19 pandemic. J. Food Biochem. 2021, 45, e13604. [CrossRef]

261. Keflie, T.S.; Biesalski, H.K. Micronutrients and bioactive substances: Their potential roles in combating COVID-19. Nutrition 2020, 84, 111103. [CrossRef]

262. Wongchitrat, P.; Shukla, M.; Sharma, R.; Govitrapong, P.; Reiter, R.J. Role of Melatonin on Virus-Induced Neuropathogenesis-A Concomitant Therapeutic Strategy to Understand SARS-CoV-2 Infection. Antioxidants 2021, 10, 47. [CrossRef] 
263. Babaei, F.; Nassiri-Asl, M.; Hosseinzadeh, H. Curcumin (a constituent of turmeric): New treatment option against COVID-19. Food. Sci. Nutr. 2020, 8, 5215-5227. [CrossRef]

264. Liu, Y.; Wang, M.; Luo, G.; Qian, X.; Wu, C.; Zhang, Y.; Chen, B.; Leung, E.L.; Tang, Y. Experience of N-acetylcysteine airway management in the successful treatment of one case of critical condition with COVID-19: A case report. Medicine 2020, 99 , e22577. [CrossRef] [PubMed]

265. Carothers, C.; Birrer, K.; Vo, M. Acetylcysteine for the Treatment of Suspected Remdesivir-Associated Acute Liver Failure in COVID-19: A Case Series. Pharmacotherapy 2020, 40, 1166-1171. [CrossRef] [PubMed]

266. Karlsson, J.O.G.; Jynge, P.; Ignarro, L.J. May Mangafodipir or Other SOD Mimetics Contribute to Better Care in COVID-19 Patients? Antioxidants 2020, 9, 971. [CrossRef]

267. Dalili, N.; Kashefizadeh, A.; Nafar, M.; Poorrezagholi, F.; Firouzan, A.; Samadian, F.; Samavat, S.; Ziaie, S.; Fatemizadeh, S. Adding Colchicine to the Antiretroviral Medication-Lopinavir/Ritonavir (Kaletra) in Hospitalized Patients with Non-Severe Covid-19 Pneumonia: A Structured Summary of a Study Protocol for a Randomized Controlled Trial. Trials 2020, $21,489$. [CrossRef] [PubMed]

268. Zhong, M.; Sun, A.; Xiao, T.; Yao, G.; Sang, L.; Zheng, L.; Zhang, L.; Jin, X.; Xu, W.; Yang, W.; et al. A Randomized, Single-blind, Group sequential, Active-controlled Study to evaluate the clinical efficacy and safety of $\alpha$-Lipoic acid for critically ill patients with coronavirus disease 2019(COVID-19). MedRxiv 2020. [CrossRef]

269. Horowitz, R.I.; Freeman, P.R.; Bruzzese, J. Efficacy of glutathione therapy in relieving dyspnea associated with COVID-19 pneumonia: A report of 2 cases. Respir. Med. Case Rep. 2020, 30, 101063. [CrossRef] [PubMed]

270. Bousquet, J.; Le Moing, V.; Blain, H.; Czarlewski, W.; Zuberbier, T.; de la Torre, R.; Pizarro Lozano, N.; Reynes, J.; Bedbrook, A.; Cristol, J.P.; et al. Efficacy of broccoli and glucoraphanin in COVID-19: From hypothesis to proof-of-concept with three experimental clinical cases. World Allergy Organ. J. 2020, 14, 100498. [CrossRef]

271. Aliter, K.F.; Al-Horani, R.A. Potential Therapeutic Benefits of Dipyridamole in COVID-19 Patients. Curr. Pharm. Des. 2020, 27, 866-875. [CrossRef]

272. Malinowska, B.; Baranowska-Kuczko, M.; Kicman, A.; Schlicker, E. Opportunities, Challenges and Pitfalls of Using Cannabidiol as an Adjuvant Drug in COVID-19. Int. J. Mol. Sci. 2021, 22, 1986. [CrossRef]

273. Tan, C.W.; Ho, L.P.; Kalimuddin, S.; Cherng, B.; Teh, Y.E.; Thien, S.Y.; Wong, H.M.; Tern, P.; Chandran, M.; Chay, J.; et al. Cohort study to evaluate the effect of vitamin $\mathrm{D}$, magnesium, and vitamin $\mathrm{B}_{12}$ in combination on progression to severe outcomes in older patients with coronavirus (COVID-19). Nutrition 2020, 79-80, 111017. [CrossRef]

274. Ding, H.; Deng, W.; Ding, L.; Ye, X.; Yin, S.; Huang, W. Glycyrrhetinic acid and its derivatives as potential alternative medicine to relieve symptoms in nonhospitalized COVID-19 patients. J. Med. Virol. 2020, 92, 2200-2204. [CrossRef]

275. Cardinali, D.P.; Brown, G.M.; Pandi-Perumal, S.R. Can Melatonin Be a Potential "Silver Bullet" in Treating COVID-19 Patients? Diseases 2020, 8, 44. [CrossRef] [PubMed]

276. Limanaqi, F.; Busceti, C.L.; Biagioni, F.; Lazzeri, G.; Forte, M.; Schiavon, S.; Sciarretta, S.; Frati, G.; Fornai, F.F. Cell Clearing Systems as Targets of Polyphenols in Viral Infections: Potential Implications for COVID-19 Pathogenesis. Antioxidants 2020, 9 , 1105. [CrossRef] [PubMed]

277. Lim, H.; Min, D.S.; Park, H.; Kim, H.P. Flavonoids interfere with NLRP3 inflammasome activation. Toxicol. Appl. Pharmacol. 2018, 355, 93-102. [CrossRef] [PubMed]

278. Barré, J.; Sabatier, J.M.; Annweiler, C. Montelukast Drug May Improve COVID-19 Prognosis: A Review of Evidence. Front. Pharmacol. 2020, 11, 1344. [CrossRef] [PubMed]

279. Lupon, E.; Lellouch, A.G.; Zal, F.; Cetrulo, C.L.; Lantieri, L.A. Combating hypoxemia in COVID-19 patients with a natural oxygen carrier, $\mathrm{HEMO}_{2}$ Life $^{\circledR}$ (M101). Med. Hypotheses 2021, 146, 110421. [CrossRef] [PubMed]

280. Maurya, V.K.; Kumar, S.; Prasad, A.K.; Bhatt, M.L.B.; Saxena, S.K. Structure-based drug designing for potential antiviral activity of selected natural products from Ayurveda against SARS-CoV-2 spike glycoprotein and its cellular receptor. Virusdisease 2020, 31, 179-193. [CrossRef] [PubMed]

281. Koh, S.S.; Ooi, S.C.; Lui, N.M.; Qiong, C.; Ho, L.T.; Cheah, I.K.; Halliwell, B.; Herr, D.R.; Ong, W.Y. Effect of Ergothioneine on 7-Ketocholesterol-Induced Endothelial Injury. Neuromolecular. Med. 2020, 1-15. [CrossRef] [PubMed]

282. Cheah, I.K.; Halliwell, B. Could Ergothioneine Aid in the Treatment of Coronavirus Patients? Antioxidants 2020, 9, 595. [CrossRef]

283. Yao, Z.H.; Yao, X.L.; Zhang, Y.; Zhang, S.F.; Hu, J.C. Luteolin Could Improve Cognitive Dysfunction by Inhibiting Neuroinflammation. Neurochem. Res. 2018, 43, 806-820. [CrossRef] [PubMed]

284. Kempuraj, D.; Thangavel, R.; Kempuraj, D.D.; Ahmed, M.E.; Selvakumar, G.P.; Raikwar, S.P.; Zaheer, S.A.; Iyer, S.S.; Govindarajan, R.; Chandrasekaran, P.N.; et al. Neuroprotective effects of flavone luteolin in neuroinflammation and neurotrauma. Biofactors 2021, 47, 190-197. [CrossRef]

285. Kempuraj, D.; Selvakumar, G.P.; Ahmed, M.E.; Raikwar, S.P.; Thangavel, R.; Khan, A.; Zaheer, S.A.; Iyer, S.S.; Burton, C.; James, D.; et al. COVID-19, Mast Cells, Cytokine Storm, Psychological Stress, and Neuroinflammation. Neuroscientist 2020, 26, 402-414. [CrossRef]

286. Ribeiro, D.E.; Oliveira-Giacomelli, Á.; Glaser, T.; Arnaud-Sampaio, V.F.; Andrejew, R.; Dieckmann, L.; Baranova, J.; Lameu, C.; Ratajczak, M.Z.; Ulrich, H. Hyperactivation of P2X7 receptors as a culprit of COVID-19 neuropathology. Mol. Psychiatry 2020, 1-16. [CrossRef] 
287. Uckun, F.M.; Carlson, J.; Orhan, C.; Powell, J.; Pizzimenti, N.M.; van Wyk, H.; Ozercan, I.H.; Volk, M.; Sahin, K. Rejuveinix Shows a Favorable Clinical Safety Profile in Human Subjects and Exhibits Potent Preclinical Protective Activity in the LipopolysaccharideGalactosamine Mouse Model of Acute Respiratory Distress Syndrome and Multi-Organ Failure. Front. Pharmacol. 2020, 11, 594321. [CrossRef]

288. Lopachev, A.V.; Kazanskaya, R.B.; Khutorova, A.V.; Fedorova, T.N. An overview of the pathogenic mechanisms involved in severe cases of COVID-19 infection, and the proposal of salicyl-carnosine as a potential drug for its treatment. Eur. J. Pharmacol. 2020, 886, 173457. [CrossRef]

289. Nagoor Meeran, M.F.; Sharma, C.; Goyal, S.N.; Kumar, S.; Ojha, S. CB2 receptor-selective agonists as candidates for targeting infection, inflammation, and immunity in SARS-CoV-2 infections. Drug Dev. Res. 2021, 82, 7-11. [CrossRef] [PubMed]

290. Berretta, A.A.; Silveira, M.A.D.; Cóndor Capcha, J.M.; De Jong, D. Propolis and its potential against SARS-CoV-2 infection mechanisms and COVID-19 disease: Running title: Propolis against SARS-CoV-2 infection and COVID-19. Biomed. Pharmacother. 2020, 131, 110622. [CrossRef] [PubMed]

291. Kulyar, M.F.; Li, R.; Mehmood, K.; Waqas, M.; Li, K.; Li, J. Potential influence of Nagella sativa (Black cumin) in reinforcing immune system: A hope to decelerate the COVID-19 pandemic. Phytomedicine 2020, 85, 153277. [CrossRef]

292. Savran, M.; Aslankoc, R.; Ozmen, O.; Erzurumlu, Y.; Savas, H.B.; Temel, E.N.; Kosar, P.A.; Boztepe, S. Agomelatine could prevent brain and cerebellum injury against LPS-induced neuroinflammation in rats. Cytokine 2020, 127, 154957. [CrossRef] [PubMed]

293. Hernández, A.; Papadakos, P.J.; Torres, A.; González, D.A.; Vives, M.; Ferrando, C.; Baeza, J. Two known therapies could be useful as adjuvant therapy in critical patients infected by COVID-19. Rev. Esp. Anestesiol. Reanim. 2020, 67, 245-252. [CrossRef] [PubMed]

294. U.S. National Library of Medicine. ClinicalTrials Page. Available online: www.clinicaltrials.gov (accessed on 22 April 2021). 